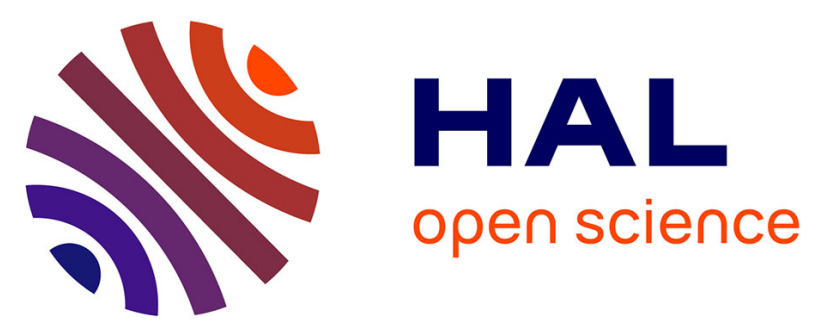

\title{
Effect of dairy matrices on the survival of Streptococcus thermophilus, Brevibacterium aurantiacum and Hafnia alvei during digestion
}

\author{
Leticia Hernandez Galan, Thomas Cattenoz, Steven Le Feunteun, Alexis \\ Canette, Romain Briandet, Sylvia Le Guin, Eric Guédon, Jessie Castellote, \\ Jérôme Delettre, Eric Dugat-Bony, et al.
}

\section{To cite this version:}

Leticia Hernandez Galan, Thomas Cattenoz, Steven Le Feunteun, Alexis Canette, Romain Briandet, et al.. Effect of dairy matrices on the survival of Streptococcus thermophilus, Brevibacterium aurantiacum and Hafnia alvei during digestion. Food Research International, 2017, 100 (1), pp.477-488. 10.1016/j.foodres.2017.07.044 . hal-01607632

\section{HAL Id: hal-01607632 \\ https://hal.science/hal-01607632}

Submitted on 26 May 2020

HAL is a multi-disciplinary open access archive for the deposit and dissemination of scientific research documents, whether they are published or not. The documents may come from teaching and research institutions in France or abroad, or from public or private research centers.
L'archive ouverte pluridisciplinaire HAL, est destinée au dépôt et à la diffusion de documents scientifiques de niveau recherche, publiés ou non, émanant des établissements d'enseignement et de recherche français ou étrangers, des laboratoires publics ou privés. 


\section{Effect of dairy matrices on the survival of Streptococcus thermophilus, Brevibacterium aurantiacum and Hafnia alvei during digestion}

Leticia Hernández-Galán $^{\mathrm{a}, \mathrm{b}}$, Thomas Cattenoz ${ }^{\mathrm{b}}$, Steven Le Feunteun ${ }^{\mathrm{b}}$, Alexis Canette ${ }^{\mathrm{c}}$, Romain Briandet $^{\mathrm{c}}$,Sylvia Le-Guin ${ }^{\mathrm{c}}$, Eric Guedon ${ }^{\mathrm{d}}$, Jessie Castellote ${ }^{\mathrm{b}}$, Jerome Delettre ${ }^{\mathrm{b}}$, Eric Dugat Bony ${ }^{\mathrm{b}}$, Pascal Bonnarme ${ }^{\mathrm{b}}$, Henry Eric Spinnler ${ }^{\mathrm{b}}$, Sandra T. Martín del Campo $^{\mathrm{a}}$, Daniel Picque ${ }^{\mathrm{b} *}$.

${ }^{a}$ Escuela de Ingeniería y Ciencias, Tecnologico de Monterrey. Epigmenio González 500, Fracc. San Pablo. CP 76130, Santiago de Querétaro, Qro. Mexico.

${ }^{\mathrm{b}}$ INRA-AgroParisTech, UMR 0782 GMPA Génie et Microbiologie des Procédés Alimentaires. Centre de recherche de Versailles-Grignon, 78850 Thiverval-Grignon, France.

c INRA-AgroParisTech, UMR 1319 MICALIS MICrobiologie de l'ALImentation au Service de la Santé Humaine. Centre de recherche Jouy-en-Josas, 78354 Jouy en Josas, France.

${ }^{\mathrm{d}}$ INRA-AGROCAMPUS OUEST, UMR 1253 STLO Science et Technologie du Lait et de l'Oeuf. Centre de recherche Rennes, 35000 Rennes, France.

${ }^{*}$ Corresponding author.

E-mail address: daniel.picque@inra.fr 


\begin{abstract}
This study evaluated the ability of dairy matrices, different in composition (with and without fat) and structure (liquid and gel), to enhance microorganisms survival through digestion. The viability of three dairy microorganisms Streptococcus thermophilus, Brevibacterium aurantiacum and Hafnia alvei was measured during in vitro and in vivo digestion. S. thermophilus was highly sensitive to gastric stress, and was not found in the duodenal compartment. $B$. auranticum was moderately sensitive to gastric stress but resistant to duodenal stress. $H$. alvei was highly resistant to both stresses. LIVE/DEAD confocal microscopy's images, probed the effect of low $\mathrm{pH}$ on microorganisms survival. However, in vivo analyses (16S rRNA gene metabarcoding) failed to confirm in vitro observations since tested microorganisms were not detected. Despite of the different evolutions during digestion on buffer capacity, lipolysis, and rheological characteristics, we did not observe any protective effect of the dairy matrices on microorganisms survival.
\end{abstract}

\title{
Keywords:
}

Digestion, microorganisms survival; dairy matrix 


\section{Introduction}

Dairy microorganisms have been recently highlighted because of their ability to survive digestive stress and interact with the intestinal microbiota producing some positive health effects (Adouard et al., 2015; Lay et al., 2004).

Some authors affirm that the presence of a dairy matrix could enhance the survival of these microorganisms during digestion (Do Espirito Santo, Perego, Converti, \& Oliveira, 2011; Ranadheera, Evans, Adams, \& Baines, 2012; Sanders \& Marco, 2009). However, literature reports are contradictory. For instance Faye, Tamburello, Vegarud, and Skeie (2012) observed that survival of L. lactis ssp. cremoris during in vitro experiments was higher in fermented milk than in synthetic medium. In contrast, Sumeri, Adamberg, Uusna, Sarand, and Paalme (2012) observed that the same microorganisms did not survive during in vitro experiments when semi-hard cheese was used. Lay et al. (2004) observed that the viability of $S$. thermophilus during in vivo experiments was greater when eaten and grown in Camembert cheese than in yogurt.

Thus, the real effect of the dairy matrix on microorganisms survival has not been fully elucidated. The mechanisms that try to explain this protective effect refers to a) the effect of the microorganism's preadaptation to the matrix b) macrostructure effects (buffer capacity and/or effects on gastric emptying rate) and c) microstructure effects (interactions between microorganisms and dairy components and/or microstructure itself).

Preadaptation effect is related to the inherent mechanism of response to stress expressed during food manufacture that produces a cross-adaptation to further digestive stress (Begley, Gahan, \& Hill, 2005; Homayoni Rad, Vaghef Mehrabany, Alipoor, \& Vaghef Mehrabany, 2016). Uriot et al. (2016) observed that viability of different strains of $S$. thermophilus to in vitro experiments was dependent on the activation of urease and small Heat Shock Proteins.

Meanwhile macrostructure effects are related mostly to the buffer capacity of the matrix during stomach phase. In this regard Gardiner, Ross, Collins, Fitzgerald, and Stanton (1998) suggested that the higher viability of E. faecium in Cheddar and yogurt during in vitro experiments was due to its higher buffer capacity compared to the synthetic medium. 
On the other hand microstructure role was suggested by Sumeri et al. (2012) who observed that survival of lactic acid bacteria during in vitro experiments was higher in semi-hard cheeses than in synthetic medium because of the higher protein content and presence of fat globules in dairy that provide a physical barrier, against digestive stress. Our study was developed in this context with the objective to test the ability, beyond preadaptation effect, of dairy matrices (milk and gel with or without fat) to enhance the survival of microorganisms, from dairy origin, $S$. thermophilus, $H$. alvei and $B$. auranticum, during digestion. The in vitro digestive model (DIDGI ${ }^{\circledR}$ ) was set using the same digestion parameters for all matrices; and the degradation of the matrix components was characterized during this digestion. In vivo experiments were also performed to observe the effect of dairy matrices on microorganism survival during full digestive transit.

\section{Material and Methods}

\subsection{Bacterial Strains}

Streptococcus thermophilus TIL 257 (ST), Brevibacterium aurantiacum ATCC9174 $(B A)$ and Hafnia alvei GB01 $(H A)$ were selected by its role during manufacture of cheese. They were obtained from the culture collection of INRA, UMR 782 Genie \& Microbiologie des Procédés Alimentaires (F-78850 Thiverval-Grignon, France).

Working cultures were reactivated from frozen stocks stored at $-80{ }^{\circ} \mathrm{C}$ by transfer $B A$ and $H A$ to Brain Heart Infusion broth (BHI), and incubation at $25^{\circ} \mathrm{C}$ with agitation. $S T$ was cultivated anaerobically in M17 at $37{ }^{\circ} \mathrm{C}$. After 48 hours, $50 \mathrm{~mL}$ of each culture was mixed with $50 \mathrm{~mL}$ of new medium and incubated $24 \mathrm{~h}$ for $B A$ and $H A$ and $18 \mathrm{~h}$ for $S T$, until reaching the stationary phase, to a final concentration of $10^{7}$ cells of each strain introduced into the DIDGI ${ }^{\circledR}$ system.

Viability during digestion was determined after dilution in Maximum Recovery Diluent (MRD, containing $\mathrm{NaCl} 8.5 \mathrm{~g} / \mathrm{L}$ and peptones $1 \mathrm{~g} / \mathrm{L}$ ) by plating on the same agar based medium used for liquid culture. The same incubation temperatures were used. All growth media were from Biokar Diagnosis (Beauvais, France), MRD was from Difco (Pessac, France).

\subsection{Dairy matrices}


Four dairy matrices with different composition and structures, skimmed milk (SM), whole milk (WM), rennet gel from skimmed milk (GSM) and rennet gel from whole milk (GWM), were used to compare its protective effect on the survival of microorganisms during dynamic in vitro digestion. Synthetic medium (S) prepared with MRD was used as control.

All dairy matrices were prepared with $10.9 \mathrm{~g}$ of skimmed milk powder $(36.2 \%$ protein, $1.5 \%$ fat, $56 \%$ lactose, $8.5 \%$ minerals; Low heat powder, Lactalis, France) diluted in $110.1 \mathrm{~mL}$ of sterile $\mathrm{CaCl}_{2}(0.01 \mathrm{M})$ and stirred for $30 \mathrm{~min}$.

WM was prepared adding $4.4 \mathrm{~g}$ of anhydrous milk fat (Lactalis, France), previously melted, to $121 \mathrm{~mL}$ of SM and mixed $5 \mathrm{~min}$ at $3000 \mathrm{rpm}$ and $50^{\circ} \mathrm{C}$ using a Thermomix (TM31, Vorwerk, Nantes, France). Then, the WM (3.8\% fat) was cooled rapidly and kept at $4{ }^{\circ} \mathrm{C}$ until analysis. GSM and GWM were prepared by mixing $121 \mathrm{~mL}$ of SM or WM with $2.4 \mathrm{~mL}$ of rennet (1:50, Naturen 450, $555 \mathrm{mg} / \mathrm{L}$ of active chymosine, 145 $\mathrm{IMCU} / \mathrm{mL}$; Chr. Hansen, Arpajon, France), the mix was gently stirred for a few seconds before being placed at $30{ }^{\circ} \mathrm{C}$ for $40 \mathrm{~min}$. Gels rheological characteristics were determined with a rotational rheometer (MCR301, Anton Paar, Ulis, France), operating in the oscillatory mode (Kristo et al., 2003, Mat et al., 2015). A mix of $18 \mathrm{~mL}$ of milk $(\mathrm{SM}$ or $\mathrm{WM})$ and $1.8 \mathrm{~mL}$ of microorganisms were introduced in the coaxial cylinder (CC27/T200/SS, Anton Paar, Ulis, France) and warmed at $30{ }^{\circ} \mathrm{C}$. Then $400 \mu \mathrm{L}$ of rennet were added and the evolution of the storage modulus $G^{\prime}$ and the loss modulus $G^{\prime \prime}$ recorded for 60 minutes. The deformation and frequency used were $1 \%$ and $1 \mathrm{~Hz}$ respectively. After $40 \mathrm{~min}$ of rennet addition, $G^{\prime}$ and $G^{\prime \prime}$ were stable and raised 28.7 $\pm 1.25 \mathrm{~Pa}$ and $7.2 \pm 0.13 \mathrm{~Pa}$ respectively. For the digestion's experiments, $4 \mathrm{~mL}$ of each microorganism were included in the matrix immediately before the in vitro digestion for liquid matrix (S, SM and WM) and just before the addition of rennet for gel matrices (GSM, GWM). Before the introduction of the matrix in the DIDGI ${ }^{\circledR}$, artificial saliva (250 $\mathrm{mg}$ of mucine and $100 \mathrm{mg} \alpha$-amylase in $100 \mathrm{~mL}$ of MRD) was added to the matrix to complete $200 \mathrm{~mL}$.

\subsection{The in vitro dynamic model of the gastrointestinal tract}

The DIgesteur Dynamique Gastro-Intestinal (DIDGI ${ }^{\circledR}$, INRA, UMR 782 GMPA) was developed to simulate digestion (Ménard et al., 2014) and it consisted of three separated 
compartments simulating the stomach, the duodenum and the small intestine controlled by the software SToRM for STomach Regulation and Monitoring (Adouard et al., 2016; Guillemin, Perret, Picque, Menard, \& Cattenoz, 2010). The digestion parameters used were previously described by Adouard et al. (2016) with some modifications (Table 1). All digestive juice components were purchased from Sigma-Aldrich (Saint-QuentinFallavier, France) and diluted in MRD.

Digestion experiments for each food matrix were performed at least by triplicate. Samples from each compartment were collected at different stages of the digestion. Microbiological counts were made immediately and samples were kept at $-20^{\circ} \mathrm{C}$ to be further analyzed.

\subsection{In vivo digestion}

Twenty four male mice $(\mathrm{CH} 3 / \mathrm{HeN})$ five weeks old were placed in a controlled room $(21$ ${ }^{\circ} \mathrm{C}$ ) with a $12 \mathrm{~h}$ light/dark cycle. Mice had free access to standard food (SAFE RO3, Augy, France, www.safe-diets.com) and sterilized water. Mice were separated in 3 groups feed differently during the five first days of the experiment. The controlled group (number 116) had only the standard feeding. The matrix group (number 152) and the matrix + microorganisms group (number 131) were respectively intragastric inoculated in the morning with $200 \mu \mathrm{L}$ of WM and WM + microorganisms. This inoculating period was followed by a seven-day standard feeding period. The feces were collected at days 1, 5 and 12, in the morning, just before inoculation. Samples were stored at $-80^{\circ} \mathrm{C}$ until analysis. All animal experiments were carried out in accordance with the directive 2010/63/EU of the European parliament and the council on the protection of animals used for scientific purposes.

\subsection{Characterization of microorganisms and matrices}

\subsubsection{Metagenomic and metatranscriptomic analysis}

For in vivo experiments, DNA extraction was performed from $30 \mathrm{mg}$ of feces as previously described (Godon, Zumstein, Dabert, Habouzit, \& Moletta, 1997). The V3V4 region of the 16S rRNA gene was amplified from $10 \mathrm{ng}$ of purified genomic DNA using the primers F343-TACGGRAGGCAGCAG and R784TACCAGGGTATCTAATCCT as previously described (Lazuka et al., 2015). Then, 
library preparation and sequencing were performed at the GeTPlaGe platform (Toulouse, France) using the Illumina MiSeq technology. Paired-end reads were merged using Flash (Magoč \& Salzberg, 2011) and FASTQ files were then quality-filtered and analyzed using QIIME v.1.9.0 (Caporaso et al., 2010). Chimeric sequences were identified using USEARCH and operational taxonomic units (OTUs) were clustered at 97\% identity using UCLUST (Edgar, 2010). Any OTU comprising less than 200 reads were removed, as recommended by Bokulich et al. (2013). Representative sequences for each OTU were classified taxonomically using RDP Classifier (Wang, Garrity, Tiedje, $\&$ Cole, 2007) against the Greengenes database (McDonald et al., 2012).

\subsubsection{Confocal laser scanning microscopy (CLSM).}

To observe the microstructure of the matrix (WM and GWM) and the location of microorganisms, milk fat was stained ( $1 \mathrm{~mL}$ of sample) with $100 \mu \mathrm{L}$ of non-polar Bodipy ${ }^{\circledR} 493 / 503$ lipid probes (working solution concentration at $0.5 \% \mathrm{w} / \mathrm{v}$ in DMSO). Proteins were stained with $100 \mu \mathrm{L}$ of amine reactive dye DyLight ${ }^{\mathrm{TM}} 550$ NHS Ester $562 / 576(0.5 \% \mathrm{w} / \mathrm{v}$ in DMSO). Microorganisms ( $1 \mathrm{~mL}$ of culture) were stained with 1 $\mu \mathrm{L}$ of the fluorescent SYTO® 61 nucleic acid stain 628/645 (commercial solution at 5 $\mathrm{mM}$ in DMSO). Then $33 \mu \mathrm{L}$ of each culture was added to the milk matrix. For gel matrix, $20 \mu \mathrm{L}$ of rennet were added to $1 \mathrm{~mL}$ of milk and placed at $37{ }^{\circ} \mathrm{C}$ for $40 \mathrm{~min}$. After gelation, samples were transferred into 96 wells $\mu$ Clear ${ }^{\circledR}$ cell culture microplate (Greiner Bio-One Kremsmünster, Austria).

In a second time, the viability of microorganism during acid stress was determined with a Filmtracer ${ }^{\mathrm{TM}}$ LIVE/DEAD ${ }^{\circledR}$ Biofilm Viability Kit including two fluorescent markers, SYTO ${ }^{\circledR} 9$ and Propidium iodide nucleic acid stains (Hannon, Lopez, Madec, \& Lortal, 2006; Stocks, 2004).

The LIVE/DEAD staining was realized only on the synthetic medium, $0.5 \mu \mathrm{L}$ of each stain was directly added to $250 \mu \mathrm{L}$ of sample in the microplate. Then $\mathrm{HCl} 0.05 \mathrm{M}$ was added to reach the concentration of $2.3 \mathrm{mM}$, corresponding to $\mathrm{pH} 2$ in the synthetic medium.

Samples were incubated in the dark at room temperature for at least 10 minutes for staining, and then mounted on the motorized stage of an inverted confocal microscope (Leica TCS SP8 AOBS, Leica Microsystems) at the MIMA2 platform 
(http://www.jouy.inra.fr/mima2/). A water immersion objective lens of 63X/1.2 N.A., (working distance $300 \mu \mathrm{m}$ ) was used. 2D sections were acquired at $600 \mathrm{~Hz}$ scan speed with bidirectional scan $X$ direction mode, with numerical zoom 1, with 512 x 512 xy image definition (pixel size $361 \mathrm{~nm}$ ), with a 8-bit dynamic range per pixel, with pinhole at Airy $1(111.5 \mu \mathrm{m}$ diameter $)$ and with a z-step of $1 \mu \mathrm{m}$.

Image analysis was carried out using ImageJ software V1.49 (NIH, Bethesda, USA).

The microscopic experiments were performed independently from DIDGI ${ }^{\mathbb{R}_{1}}$ s one.

\subsubsection{Matrix buffer capacity}

The amount of $\mathrm{HCl}$ used to reach $\mathrm{pH} 2$ in the stomach phase of DIDGI ${ }^{\circledR}$ system was determined through the SToRM software for each tested matrix. The resulting $\mathrm{pH}$ titration curves were used to calculate the buffer capacity through equation (Eq.1) (Salaün, Mietton, \& Gaucheron, 2005).

$$
\frac{d B}{d p H}=\frac{\text { Volume of acid }(\mathrm{mL}) \times \text { Normality of the acid }}{\text { Changes in } p H \times \text { volume of sample }} \ldots \ldots \ldots \ldots \ldots \ldots \ldots . . . \ldots \text {.... } 1
$$

As described by Upreti, Bühlmann, and Metzger (2006), sample's dilution with the acid was considered insignificant for buffering curves.

\subsubsection{On line torque measurement}

Rheological characteristic of dairy matrices was measured on-line during gastric digestion. These experiments were conducted simultaneously with DIDGI ${ }^{\mathbb{B}_{1}} \mathrm{~s}$ ones with a specific system developed and adapted to the rheometer used before (section 2.2). The system was composed by a glass vessel (high $165 \mathrm{~mm}$, diameter $80 \mathrm{~mm}$ ) surrounded with a heating mat to control temperature. The stirrer consisted of four stainless steel agitation blades (high $20 \mathrm{~mm}$, long $35 \mathrm{~mm}$ ) connected to the rheometer. The turbine blades were fully immerse in $200 \mathrm{~mL}$ of the matrix in the glass vessel. A pH, redox and temperature probe (Electrode InPro 480i/SG/120, reference 52003581, Mettler Toledo, France) was connected to the SToRM software to measure and control the conditions during the experiment.

As described for DIDGI ${ }^{\circledR}$ 's experiments, $200 \mathrm{~mL}$ of S, SM, WM, GSM or GWM were introduced in the glass vessel of the rheometer. Rennet gels were cut in cubic pieces 
with edges of $1.5 \mathrm{~cm}$ just before the introduction. The stirrer and the $\mathrm{pH}$ probe were placed in the matrix and the measurement of the torque began. Pepsin and $\mathrm{HCl}$ were incorporated in the same conditions than for the digestion (Table 1). The rotating speed of the stirrer was $60 \mathrm{rpm}$.

\subsubsection{Sodium dodecyl sulfate-polyacrylamide gel electrophoresis (SDS-PAGE)}

Prior to analysis, samples kept at $-20{ }^{\circ} \mathrm{C}$ were defrosted and homogenized during $15 \mathrm{~s}$ at $15500 \mathrm{rpm}$ using an Ultraturrax (T25, Janke \& Kunkel, Staufen, Germany). Samples were stabilized at $25^{\circ} \mathrm{C}$ for $20 \mathrm{~min}$ before analysis.

For the SDS-PAGE analysis, protein contents were calculated using the method reported by Lüthi-Peng and Puhan (1999) with slight modifications. Briefly, $100 \mu \mathrm{L}$ of sample were diluted in $1900 \mu \mathrm{L}$ of $6 \mathrm{M}$ guanidine- $\mathrm{HCl}$ in $0.1 \mathrm{M} \mathrm{Na}$ acetate buffer, pH5.0. The absorbance was measured at 280-320 nm (spectrophotometer Evolution 201, ThermoFisher Scientific, France) and used to calculate the protein content. The calibration curve was performed with the same dairy proteins from the skimmed milk powder.

SDS-PAGE was performed using the 4-12\% polyacrylamide NuPAGE SDS-PAGE precast gels (ThermoFisher Scientific, France). Samples were diluted (with running buffer) to reach a final concentration of $10 \mu \mathrm{g}$ of proteins to be loaded in each lane. Gels were fixed in $700 \mathrm{~mL}$ of 20X NuPAGE MES SDS running buffer. Running was at 60 $\mathrm{mA} / \mathrm{gel}$ and $120 \mathrm{~V}$ for $2 \mathrm{~h}$. After washing $3 \times 5 \mathrm{~min}$ with deionized water, gels were stained $1 \mathrm{~h}$ with Colloidal Blue Staining Kit (Simply Blue Safe Stain, ThermoFisher Scientific, France). A low molecular weight marker (SeeBluePlus 2, ThermoFisher Scientific, France) was used to identify the proteins in the gel. At least 2 gels were run of each food matrix. Image analysis of SDS-PAGE gels was carried out using PDQuest 2-D analysis software, version 6.2.1.

\subsubsection{Free fatty acid by $G C$}

For free fatty acid (FFA) extraction, $50 \mu \mathrm{L}$ of sample were mixed with $100 \mu \mathrm{L}$ of internal standard solution $\left(0.49 \mu \mathrm{g}\right.$ tridecanoic acid $/ \mathrm{mL}$ in $\left.\mathrm{CHCL}_{3}\right)$ and dehydrated with $\mathrm{Na}_{2} \mathrm{SO}_{4}$ anhydrous; then extracted twice with $1 \mathrm{~mL}$ of diethyl ether/heptane $(1: 1 \mathrm{v} / \mathrm{v})$ 
and shaken vigorously for $3 \mathrm{~min}$. The organic supernatant was separated and both extracts were combined.

Solid phase extraction (SPE) of FFA was performed as described by Voigt, Chevalier, Qian, and Kelly (2010). Solvent was evaporated to dryness with a speed-vac system (ThermoFisher Scientific, France) and dissolved with $100 \mu \mathrm{L}$ of $\mathrm{CHCl}_{3}$, put in a tight closed micro-vials.

FFA extracts were analyzed by gas chromatography (Agilent Technologies 6890, Palo Alto, Ca.) coupled with a mass selective detector (MS 5973N, Agilent Technologies, France) and a CTC autosampler (CombiPAL, Agilent Technologies, France).

FFA were separated with a DB-FFAP column $(30 \mathrm{~m} \times 250 \mu \mathrm{m} \times 0.25 \mu \mathrm{m}$, Agilent Technologies, France) using Helium as carrier gas at $1.2 \mathrm{~mL} / \mathrm{min}$. Oven temperature was set at $40{ }^{\circ} \mathrm{C}$ for $1 \mathrm{~min}$, then increased at $10{ }^{\circ} \mathrm{C} / \mathrm{min}$ to $240{ }^{\circ} \mathrm{C}$ and hold $30 \mathrm{~min}$. Injector was set at $250{ }^{\circ} \mathrm{C}$ in splitless mode and $1 \mu \mathrm{L}$ sample was injected. Mass spectra were recorded at $70 \mathrm{mV}$ in the total ion mode (SCAN) with an $\mathrm{m} / \mathrm{z} 33-550$.

Quantification was performed with the internal standard method. FFA reference compounds were provided by Sigma-Aldrich with a minimum purity of $98 \%$. Standard calibration curves had a concentration of $0.35-935.0 \mu \mathrm{g} / \mathrm{mL}$ and were considered satisfactory when $r^{2} \geq 0.980$.

\subsection{Statistics analysis}

Statistical analysis was performed using Statistica V12 (Statsoft Inc., Tulsa, OK, USA). Results were expressed as the mean \pm standard deviation of the three biological independent experiments and were compared using a Student's test. Differences were considered statistically significant when $p<0.01$. The comparison of the strains survival rates was performed independently in each compartment. For each strain, at each sampling time, Student's test was used to study the effect of the medium. For each strain in one medium, Student's test was used to study the effect of the time. For FFA, analysis of variance (ANOVA) and the Fisher's least square differences (LSD) were applied, they were considered statistically different when $p<0.05$.

\section{Results}




\subsection{Survival of the microorganism to digestion}

\subsubsection{In vitro experiments.}

The effect of in vitro digestive stress on the survival of $H A, B A$ and $S T$ was tested in the dynamic digester DIDGI ${ }^{\circledR}$ and the protective effects of different dairy matrices (S, SM, WM, GSM, GWM) were compared (Figure 2 and 3). The strains exhibited different behavior in each digestive compartment.

\subsubsection{Hafnia alvei}

$H A$ was the most resistant microorganism during all the digestion process. In stomach it remained constant during the first $60 \mathrm{~min}$ (Figure 1A) whatever the matrices with no significant statistical difference except at $60 \mathrm{~min}$ for GSM. Then, at $70 \mathrm{~min}$, the viability began to decrease with an average loss of $2.6 \log \mathrm{CFU} / \mathrm{mL}$ at the end of gastric phase. Slight differences between matrices were observed at the end of this phase (100 $\mathrm{min})$. The viability decreased in all the matrices to less than $5 \log \mathrm{CFU} / \mathrm{mL}$ except in SM media, for which the level was $5.56 \log \mathrm{CFU} / \mathrm{mL}$. The strong resistance of $H A$ to acid stress was confirmed by LIVE/DEAD results with only $2 \%$ of microorganism with compromised membranes (red color) after $20 \mathrm{~min}$ incubation at pH2 (Figure 3A).

During the duodenal phase, $H A$ showed also strong resistance and the viability remained constant between 6.5 to $7.2 \log \mathrm{CFU} / \mathrm{mL}$ for the first $60 \mathrm{~min}$ (Figure 1B). Then, it fell losing on average $1.03 \log \mathrm{CFU} / \mathrm{mL}$ at the end of this phase. Slight differences were observed between matrices at $120 \mathrm{~min}$. S and WM media exhibited higher viability (6.37 $\log \mathrm{CFU} / \mathrm{mL}$ ) than other matrices $(5.57 \log \mathrm{CFU} / \mathrm{mL})$, however these differences were not significant.

$H A$ showed strong resistance to the stress in the intestinal phase (Figure 1C). All the matrices displayed similar initial level of viability in the small intestine $(7.06 \pm 0.05 \mathrm{log}$ $\mathrm{CFU} / \mathrm{mL}$ at $50 \mathrm{~min}$.). Levels in S, WM, GSM and GWM remained constant over 140 min of intestinal digestion; while in SM loss of viability was more evident. At 170 min, there were significant differences $(p<0.01)$ between matrices. S, SM and GSM viability remained statistically constant. The counts of $H A$ in WM fell gradually after 170 min until lose $2.6 \log \mathrm{CFU} / \mathrm{mL}$ by the end of the experiment. The same behavior was observed in GWM. After $200 \mathrm{~min}$, the level of $H A$ had a significant drop of viability (1.3 $\log \mathrm{CFU} / \mathrm{mL})$ compared with the initial value at $50 \mathrm{~min}$ (Figure 1C). 
Viability of $H A$ could be attributed to the presences of an outer membrane, characteristic of all the gram-negative bacteria that provide them with an extra protection to all kind of environmental stresses. Additionally $H A$ is an ornithine and urease positive bacteria (Janda \& Abbott, 2006), both enzyme increases the $\mathrm{pH}$ through decarboxylation and production of ammoniac respectively. However both enzymes could be later inactivated by the action of the enzymes present in digestion, thus the real mechanism of response of $H A$ could be more related to genetic adaptation. By its approach with E. coli we could attribute its high survival rate to the effect of efflux pumps or a cross-adaptation to the previous mechanism related to the acidity stress (Begley et al., 2005).

\subsubsection{Brevibacterium aurantiacum}

$B A$ was sensitive to gastric stress as shown in figure $2 \mathrm{~A}$. For each medium, its viability decreased slightly, $0.38 \log \mathrm{CFU} / \mathrm{mL}$ during the first $30 \mathrm{~min}$. Slight statistical differences between matrices were observed during the first $30 \mathrm{~min}$ of gastric digestion. When $\mathrm{pH}$ reached to 2.7 (50 $\mathrm{min})$, viability decreases on average $1.25 \log \mathrm{CFU} / \mathrm{mL}$ without any statistically significant difference $(p<0.01)$ between matrices. At $60 \min B A$ was only found in SM at $3.92 \pm 0.97 \log \mathrm{CFU} / \mathrm{mL}$. However, high numbers of microorganisms were capable to reach the duodenal phase during the first thirsty minutes (7.9 and 8.6 $\log \mathrm{CFU}$ ). Moderately sensitivity of BA to acid stress was also observed during LIVE/DEAD experiments with 11\% of damaged cells (Figure 3B). Gastric sensitivity of this microorganism was not surprising since during cheese ripening it grows only when cheese $\mathrm{pH}$ reaches 6-7 (Irlinger et al., 2012).

$B A$ was resistant to duodenal stress (Figure $2 \mathrm{~B}$ ), its viability decreases constantly, losing only on average $1.73 \log \mathrm{CFU} / \mathrm{mL}$ in all matrices over the duodenal exposure. The drop was faster for SM and GWM matrices which exhibited the lowest levels at $120 \mathrm{~min}$.

When $B A$ reached the intestine, its initial concentration was between $6.71 \log \mathrm{CFU} / \mathrm{mL}$ and $5.47 \log \mathrm{CFU} / \mathrm{mL}$ respectively for $\mathrm{WM}$ and $\mathrm{SM}$ matrix (Figure 2C). All the matrices displayed similar behavior until $140 \mathrm{~min}$. Differences observed between the matrices during this time were not statistically significant and attributed to differences in the initial count in this compartment. After 140 min, significant differences between 
matrices were observed. From $170 \mathrm{~min}$ to $230 \mathrm{~min}, B A$ could only been found in $\mathrm{S}$ and SM, meanwhile the viability of WM, GSM and GWM descended below the detection limit of the plating method.

This behavior can be related with BA ability to survive in cheese surface even when it is salted in many occasions (Irlinger et al., 2012). Genoma of B. auranticum 9174 exhibits an important number of osmoprotectant transporters (Monnet, Landaud, Bonnarme, \& Swennen, 2014) which might provide it a further cross-adaptation to other stress (Begley et al., 2005).

\subsubsection{Streptococcus thermophilus}

$S T$ was highly sensitive to the gastric phase remaining viable only $30 \mathrm{~min}$ in the stomach $(4.39 \pm 1.7 \log \mathrm{CFU} / \mathrm{mL})$. Within the next 10 minutes (below pH4.6) the concentration decreased quickly dropping under our detection limit (data not shown). LIVE/DEAD staining confirmed the sensitivity of $S T$ with $40 \%$ of damaged cells after $20 \mathrm{~min}$ at $\mathrm{pH} 2$ (Figure 3C).

These results are in accordance with Adouard et al. (2016) who observed that ST did not survive to neither gastric in vitro digestion and partially in agreement with those of Marteau, Minekus, Havenaar, and Huis In't Veld (1997) and García-Hernández, Moreno, Chuan, and Hernández (2012) who observed that ST survived only briefly in the gastric phase during in vitro digestion of yogurt.

In the subsequent compartments of the DIDGI ${ }^{\circledR}, S T$ was no longer found in any of the tested matrices.

\subsubsection{In vivo experiments.}

A total of 3,103,358 16S rRNA (V3-V4 regions) sequencing reads were generated from the 72 mice fecal samples. An average of 36,577 sequences per sample were obtained after quality filtering and chimera removal. They were clustered into 244 bacterial OTUs with an abundance $>200$ sequences in the entire dataset.

Our in vivo analysis failed to demonstrate the survival of $B A, H A$ and $S T$ after digestion. Traces of Streptococcus were found in feces but were further attributed to a similar strain part of the GI tract (S. salivarius subsp. salivarius) as previously suggested by Bogovic-Matijasic et al. (2015). Our results are in agreement with those of del Campo 
et al. (2005) who observed that $S T$ part of fresh yogurt, was not capable to survive through in vivo digestion; and in disagreement with those of Lay et al. (2004) who found that when part of Camembert cheese $S T$ was capable to survive in vivo digestion but not when it was part of fermented milk; suggesting that a solid matrix was more effective than a liquid one. However in our results, we did not observe any increase in viability when gel was used instead of milk.

The bacterial community structure did not vary neither according to the day of sampling nor the food matrix used for feeding (Figure 4), which indicated that the treatment did not modify the overall composition of the mouse microbiota.

\subsection{Chemical and physical characterization of matrices during the digestion}

The initials states of WM and GWM structure were visualized by CLSM just after mixing with the strains $(\mathrm{pHi}=6.5)$. Milk proteins were colored in yellow and had a characteristic structure of milk protein powder particles as describe by Mimouni, Deeth, Whittaker, Gidley, and Bhandari (2010). Fat spherical globules appeared in green and microorganisms in bright red color (Figure 3D). When the milk was coagulated by rennet, proteins formed a porous network surrounded by lactoserum (unstained components) and containing different sizes fat globules (Figure 3E). The distribution of microorganisms was not different between liquid and gel matrices.

\subsubsection{Protein profiles during in vitro digestion}

SDS-PAGE profiles are shown in figure 5. Dairy matrices with or without fat presented very similar trends therefore only results with fat are shown. Caseins were hydrolyzed all along the stomach phase without significant differences between gel and milk matrices. At 10 minutes, 10 to $15 \%$ of the caseins were hydrolyzed and at the end of the stomach phase $70 \%$ remained intact (figure $6 \mathrm{~A}$ ).

This is in accordance with the result of Inglingstad et al. (2010) and Rinaldi, Gauthier, Britten, and Turgeon (2014) while working with in vitro digestion of proteins from different animal origin in liquid and semi-liquid matrixes, respectively. In contrast, our results are much higher than those reported by Gallier, Ye, and Singh (2012) during the in vitro digestion of bovine milk and Bourlieu et al. (2015) during the in vivo digestion of a standardized milk emulsion. These differences can probably be explained by the 
milk origin and preparation; as well as the type, amount and activity of the enzymes used in the experiments (Almaas et al., 2006).

In our work, the whey proteins remained intact during the gastric digestion (figure 5 and 6B), as observed by Kopf-Bolanz et al. (2014) when they studied the impact of milk processing on the generation of peptides during digestion.

\subsubsection{Free fatty acid profiles}

Free fatty acid (FFA) released during digestion of WM and GWM are shown in figure 8. For both matrices the most abundant FFA were C16:0, C18:1 n9, and C18. Short chain FFA (C6-C10) showed low concentrations throughout digestion.

For both WM and GWM, all the analyzed FFA showed significant differences $(p<0.05)$ according with the digestion time except C18:2 in WM. Instead, significant differences were observed between matrices for all the FFA except for C6 and C20:0. Globally, FFA release was higher in WM than in GWM except at the end of digestion (230 min) where values were higher in GWM. Both matrices showed a lower FFA release during the stomach digestion than in the intestinal phase.

In the stomach, lipolysis rate was significantly higher for WM than GWM for most of the analyzed FFA. For WM, FFA concentration remained steady throughout gastric digestion, while for GWM it was higher at the beginning of digestion remaining steady between 30 and $60 \mathrm{~min}$. The lower release of FFA observed during the stomach lipolysis could be attributed to the Rhizopus oryzae lipase used and to the lack of pregastric lipase in the artificial saliva. Nevertheless, we observed higher values in stomach lipolysis for both WM and WMG than those reported by Devle et al. (2014) for milk digestion using human gastrointestinal juice.

Meanwhile, in the intestine the lipolysis was higher than in the stomach for both matrices. For WM (Figure 7B) the behavior depended on the chain length, short chain FFA (C6-C12) remained steady between 50 and $110 \mathrm{~min}$ increasing at the end of intestinal phase; medium chain saturated FFA (C14-C18) and C16:1 fluctuated throughout intestine digestion; while C20 increased constantly. For GWM (Figure 7A), most of the evaluated FFA increased steadily throughout digestion reaching higher values than in WM except for C16:1 and C20 that remained constant and increased only 
at the end of intestine digestion. The release and profiles of FFA in the intestine for both WM and WMG were similar to the results reported before by DePeters, German, Taylor, Essex, and Perez-Monti (2001) and Devle et al. (2014) for milk digestion with human duodenal juices. Even though the antimicrobial activity attributed to C6 and C8 against gram-negative bacteria (Turgeon \& Rioux, 2011), no significant correlations were found between the individual FFA and $H A$ survival at the intestine. The concentrations obtained in this study were inferior to the minimum inhibitory concentration reported by Sun, O'Connor, and Roberton (2002).

\subsubsection{Rheological properties of milks and gels during digestion}

The evolution of torque of all matrices was measured during gastric digestion (Figure 8). To highlight the role of the digestion on the evolution of the matrix, effect of cutting and stirring on the rennet gel was tested replacing pepsin and $\mathrm{HCl}$ by water (GelMechanical action only in figure 8). In these conditions without enzyme and acidification, initial torque of gel was $0.6 \mathrm{mN} / \mathrm{m}$, descended slowly to $0.4 \mathrm{mN} / \mathrm{m}$ at 60 min and remained steady until the end. Cutting gel creates more surface where syneresis can occur (Janhoj \& Qvist, 2010) and stirring enhance syneresis by preventing sedimentation and rising pressure on the curd (Guinee \& O'Callaghan, 2010).

Since there were no differences between matrices with or without fat, the average and standard error of the torque for milk and rennet gel with and without fat were calculated. Contrary to the observations of Devle et al. (2012) who founded differences in viscosity between skim milk and homogenized full fat milk. The authors attributed the differences observed to an effect of softening by the large fat globule. Besides, we can think that our module of torque measure is not enough sensitive to differentiate low gap of viscosity.

Significant differences were observed between milk and rennet gel. For milk matrix, torque decreased from 0.15 to $0.05 \mathrm{mN} / \mathrm{m}$ after $40 \mathrm{~min}$ and remained steady. This behavior might be due to the effect of stirring, that did not allow the formation of a homogeneous acid curd. However we observed flocculation in the reactor. 
For rennet gel the torque decreased swiftly from the initial 0.6 to $0.5 \mathrm{mN} / \mathrm{m}$ in the first minutes of digestion. Then it continued decreasing linearly during 50 min until 0.15 $\mathrm{nM} / \mathrm{m}$. Between 55-70 minutes the signal increased slightly to $0.18 \mathrm{mN} / \mathrm{m}$. After this period, torque went back down slowly and remained steady until the end of the experiment. As described by Johnson and Law (2010), the $\mathrm{HCl}$ addition conduct to low $\mathrm{pH}$ in the vessel, reducing the water present in the casein micelles and solubilizing calcium. Thus, the structure of the micelles changed, forming new bonds between caseins, reducing the size of the curd and increasing its permeability; therefore syneresis increased (Barbé et al., 2014). This phenomenon was relatively slow until pH5.5, but when $\mathrm{pH}$ decreased, syneresis increased and reached its maximum at $\mathrm{pH} 4.7-4.9$ probably due to a reduction of overall charge as the isoelectric point of the casein is approached.

The decrease of torque below pH4.7 also might be attributed to the action of pepsin, since the optimum pH zone is 2-4 (Schlamowitz \& Peterson, 1959). The key role of the pepsin on the reduction of viscosity has been previously described by Prakash, Ma, and Bhandari (2014).

The further increase of torque between 60-80 min might be attributed to the aggregation of the micelles. During this phase, the kinetics of aggregation became more important than the hydrolysis by the pepsin and the size of the aggregates increased as the viscosity, as observed for the milk but with a lesser intensity.

\subsubsection{Matrices buffering capacity}

For in vitro digestions, the quantity of acid needed to reach $\mathrm{pH} 2$ in the stomach phase was dependent on the type of matrix. Thus, the quantity of $\mathrm{HCl}$ used increased proportionally to the complexity of the matrix, imitating the in vivo conditions were the acid secretion in the stomach is highly related to the nature of the bolus (Kong \& Singh, 2008). However, fat addition in our dairy matrices was not significant for acidification in the gastric phase. The average amount of $\mathrm{HCl}$ necessary to reach $\mathrm{pH} 2$ for milks (SM, WM) and for gels (GSM, GWM) was respectively $10.6 \pm 0.02 \mathrm{mM}$ and $11.5 \pm 0.6 \mathrm{mM}$. For the synthetic medium only $2.7 \pm 0.4 \mathrm{mM}$ of $\mathrm{HCl}$ were sufficient to reach $\mathrm{pH} 2$. 
The buffer capacity $(\mathrm{dB} / \mathrm{dpH})$ in the gastric phase was determined mathematically from the $\mathrm{pH}$ titration curves measured in the DIDGI ${ }^{\circledR}$ system (Figure 9).

When the synthetic medium, containing only low concentrations of $\mathrm{NaCl}$ and peptones, was acidified from pH6.5 to $2, \mathrm{~dB} / \mathrm{dpH}$ remained stable from $\mathrm{pH} 5.5$ to $3.5(\mathrm{~dB} / \mathrm{dpH}<$ $0.005)$. Then, it increased to reach 0.0125 at $\mathrm{pH} 2.2$.

The buffering capacity of milk increased from 0.08 at pH6.5 to 0.017 at pH5.2, its maximum value. Then, $\mathrm{dB} / \mathrm{dpH}$ decreased to 0.015 at $\mathrm{pH} 5$ and remained stable until the end of the experiment. For gels, the buffering capacity rise from about 0.09 at $\mathrm{pH} 6.5$ to 0.024 at $\mathrm{pH} 2.75$ and then decreased to 0.015 at $\mathrm{pH} 2$.

Between pH6.5 and pH5, dB/dpH was higher for milks than for gels. For $\mathrm{pH}$ lower than 5 , we observed the opposite phenomenon.

Our $\mathrm{dB} / \mathrm{dpH}$ curves were similar to those reported by Salaün et al. (2005) and Upreti et al. (2006) who found two maximal dB/dpH. Lucey, Hauth, Gorry, and Fox (1993) attributed the peak at about $\mathrm{pH}-5.5$ to the solubilization of colloidal calcium phosphate and a strong increase below $\mathrm{pH} 3$ due to acidic amino acids present in caseins. In rennetcurdled skim milk, Whittier (1929) described a maximal $\mathrm{dB} / \mathrm{dpH}$ at $\mathrm{pH} 4.7$ and the difference with milk was ascribed to the production of para casein by the rennet and to the coagulum structure. Lucey et al. (1993) found a buffering peak at pH4.2 during the titration of rennet whey.

Furthermore it is well known that buffer capacity depends of the type of dairy product (Salaün et al., 2005; Upreti et al., 2006) since matrix with the same components have not necessarily the same structural organization or same digestion kinetic (Rinaldi et al., 2014; Turgeon \& Rioux, 2011). Higher buffer capacity in gel than in liquid could be due to a structural effect, where the curd traps the elements that give the buffer capacity, longer than a liquid matrix (Salaün et al., 2005).

In this regard, two main factors need to be considered, the action of the pepsin during the gastric phase and the dynamic evolution of digestion. Hydrolysis of milk proteins and the peptide released during the in vitro gastric digestion can modify the buffer capacity; through increasing the number of available ionizable groups (i.e. acidic amino acids) that before were inaccessible (Salaün et al., 2005). The dynamic functioning of 
the in vitro digester with a continuous transfer between the various compartments also modifies the composition of the matrix and consequently the buffer capacity.

Still, despite the higher buffer effect of dairy matrices, compared with synthetic medium, in our results we did not observe a protective effect on microorganisms survival through digestion. Our results are in disagreement with the previous works of Conway, Gorbach, and Goldin (1987) and Charteris, Kelly, Morelli, and Collins (1998) who in different works with probiotics suggested that milk proteins improved the gastric transit tolerance of microorganisms, because of its tampon effect. Though, our results are in accordance with the reported by Adouard et al. (2016) who observed that survival of Corynebacterium casei and Staphylococcus equorum during in vitro digestion was similar when contained in cheese or synthetic medium.

\section{Conclusions}

In this work, we studied the effect of dairy matrices different in composition (with and without fat) and structure (liquid and gel) on microorganisms survival through digestion. The tested microorganisms had different survival rates during digestion.

Therefore our results suggest that protective effect of the dairy matrices during digestion is not dependent of buffer capacity or interactions between microorganisms and dairy matrices (components and microstructure). Suggesting that factors that provide protection during digestion could be strain-dependent. During in vitro assays digestion parameters, such as gastric emptying and duration of digestion, were set the same for all the tested matrices; however during in vivo digestion, these parameters change according to the type of food matrix.

\section{Acknowledgements}

First author would like to thank the Consejo Nacional de Ciencia y Tecnología (CONACyT) for her Ph.D. scholarship (211892).

Funding: This research did not receive any specific grant from funding agencies in the public, commercial, or not-for-profit sectors. 


\section{References}

Adouard, N., Foligné, B., Dewulf, J., Bouix, M., Picque, D., \& Bonnarme, P. (2015). In vitro characterization of the digestive stress response and immunomodulatory properties of microorganisms isolated from smear-ripened cheese. International Journal of Food Microbiology 197, 98-107. doi:

10.1016/j.ijfoodmicro.2014.12.011

Adouard, N., Magne, L., Cattenoz, T., Guillemin, H., Foligné, B., Picque, D., \& Bonnarme, P. (2016). Survival of cheese-ripening microorganisms in a dynamic simulator of the gastrointestinal tract. Food Microbiology, 53 part A, 30-40. doi: 10.1016/j.fm.2015.03.002

Almaas, H., Casses, A., Devold, T. G., Halvor, H., Langsrud, T., Aabakken, L., . . Vegarud, G. E. (2006). In vitro digestion of bovine and caprine milk by human gastric and duodenal enzymes. International Dairy Journal 16(9). doi:

10.1016/j.idairyj.2005.10.029

Barbé, F., Le Feunteun, S., Rémond, D., Ménard, O., Jardin, J., Henry, G., . . . Dupont, D. (2014). Tracking the in vivo release of bioactive peptides in the gut during digestion: Mass spectrometry peptidomic characterization of effluents collected in the gut of dairy matrix fed mini-pigs. Food Research International, 63, Part B, 147-156. doi: http://dx.doi.org/10.1016/j.foodres.2014.02.015

Begley, M., Gahan, C. G. M., \& Hill, C. (2005). The interaction between bacteria and bile. [Review]. FEMS Microbiology Reviews, 29, 625-651. doi:

10.1016/j.femsre.2004.09.003

Bogovic-Matijasic, B., Obermajer, T., Lipoglavsek, L., Sernel, T., Locatelli, I., Kos, M., ... Rogelj, R. (2015). Effects of synbiotic fermented milk containing Lactobacillus acidophilus La-5 and Bifidobacterium animalis ssp. lactis BB-12 
on the fecal microbiota of adults with irritable bowel syndrome: A randomized double-blind, placebo-controlled trial. journal of Dairy Science, 99, 1-14. doi: 10.3168/jds.2015-10743

Bokulich, N. A., Subramanian, S., Faith, J. J., Gevers, D., Gordon, J. I., Knight, R., . . . Caporaso, J. G. (2013). Quality-filtering vastly improves diversity estimates from Illumina amplicon sequencing. Nature methods, 10(1), 57-59.

Bourlieu, C., Ménard, O., De La Chevasnerie, A., Sams, L., Rousseau, F., Madec, M.N., . . Dupont, D. (2015). The structure of infant formulas impacts their lipolysis, proteolysis and disintegration during in vitro gastric digestion. Food Chemistry, 182, 224-235. doi: http://dx.doi.org/10.1016/j.foodchem.2015.03.001

Caporaso, J. G., Kuczynski, J., Stombaugh, J., Bittinger, K., Bushman, F. D., Costello, E. K., . . Gordon, J. I. (2010). QIIME allows analysis of high-throughput community sequencing data. Nature methods, 7(5), 335-336.

Conway, P. L., Gorbach, S. L., \& Goldin, B. R. (1987). Survival of Lactic Acid Bacteria in the Human Stomach and Adhesion to Intestinal Cells. Journal of Dairy Science, 70(1), 1-12. doi: http://dx.doi.org/10.3168/jds.S0022-0302(87)79974-3

Charteris, W. P., Kelly, P. M., Morelli, L., \& Collins, J. K. (1998). Development and application of an in vitro methodology to determine the transit tolerance of potentially probiotic Lactobacillus and Bifidobacterium species in the upper human gastrointestinal tract. Journal of Applied Microbiology 84, 759-768. doi: 10.1046/j.1365-2672.1998.00407.x

del Campo, R., Bravo, D., Cantón, R., Ruiz-Garbajosa, P., García-Albiach, R., MontesiLibois, A., .. . Baquero, F. (2005). Scarce Evidence of Yogurt Lactic Acid Bacteria in Human Feces after Daily Yogurt Consumption by Healthy 
Volunteers. Applied and Enviromental Microbiology, 71(1), 547-549. doi:

10.1128/AEM.71.1.547-549.2005

DePeters, E. J., German, J. B., Taylor, S. J., Essex, S. T., \& Perez-Monti, H. (2001).

Fatty Acid and Triglyceride Composition of Milk Fat from Lactating Holstein

Cows in Response to Supplemental Canola Oil. Journal of Dairy Science, 84(4), 929-936. doi: http://dx.doi.org/10.3168/jds.S0022-0302(01)74550-X

Devle, H., Naess-Andresen, C. F., Rukke, E.-O., Vegarud, G. E., Ekeberg, D., \& Schüller, R. B. (2012). Rheological characterization of milk during digestion with human gastric and duodenal enzymes. Annual Transactions of the Nordic Rheology Society, 20.

Devle, H., Ulleberg, E. K., Naess-Andresen, C. F., Rukke, E.-O., Vegarud, G., \& Ekeberg, D. (2014). Reciprocal interacting effects of proteins and lipids during ex vivo digestion of bovine milk. International Dairy Journal, 36(1), 6-13. doi: http://dx.doi.org/10.1016/j.idairyj.2013.11.008

Do Espirito Santo, A. P., Perego, P., Converti, A., \& Oliveira, M. N. (2011). Influence of food matrices on probiotic viability - A review focusing on the fruity bases. Trends in Food Science and Technology 22, 377-385. doi: 10.1016/j.tifs.2011.04.008

Edgar, R. C. (2010). Search and clustering orders of magnitude faster than BLAST. Bioinformatics, 26(19), 2460-2461. doi: 10.1093/bioinformatics/btq461

Faye, T., Tamburello, A., Vegarud, G. E., \& Skeie, S. (2012). Survival of lactic acid bacteria from fermented milks in an in vitro digestion model exploiting sequential incubation in human gastric and duodenum juice. Journal of Dairy Science, 95, 558-566. doi: 10.3168/jds.2011-4705 
Gallier, S., Ye, A., \& Singh, H. (2012). Structural changes of bovine milk fat globules during in vitro digestion Journal of Dairy Science, 95(7). doi: 10.3168/jds.20115223

García-Hernández, J., Moreno, Y., Chuan, C., \& Hernández, M. (2012). In Vivo Study of the Survival of Lactobacillus delbruecki subsp. bulgaricus CECT 4005T and Streptococcus thermophilus CECT 801 by DVC-FISH after Consumption of Fermented Milk. Journal of Food Science, 77(10), M593-M597. doi: 10.1111/j.1750-3841.2012.02918.x

Gardiner, G., Ross, R. P., Collins, J. K., Fitzgerald, G., \& Stanton, C. (1998). Development of a Probiotic Cheddar Cheese Containing Human-Derived Lactobacillus paracasei Strains. Applied and Enviromental Microbiology, 64(6), 2192-2199.

Godon, J. J., Zumstein, E., Dabert, P., Habouzit, F., \& Moletta, R. (1997). Molecular microbial diversity of an anaerobic digestor as determined by small-subunit rDNA sequence analysis. Applied and Environmental Microbiology, 63(7), $2802-2813$.

Guillemin, H., Perret, B., Picque, D., Menard, O., \& Cattenoz, T. (2010). Logiciel StoRM-stomach and duodenum regulation and monitoring. IDDNFR001230009000RP201000031235, 290.

Guinee, T. P., \& O'Callaghan, D. J. (2010). The formation of Cheese Curd. In B. A. Law \& A. Y. Tamime (Eds.), Techology of Cheesemaking (pp. 260-314). United Kingdom Wiley-Blackwell.

Hannon, J. A., Lopez, C., Madec, M. N., \& Lortal, S. (2006). Altering Renneting pH Changes Microstructure, Cell Distribution, and Lysis of Lactococcus lactis AM2 
in Cheese Made from Ultrafiltered Milk. Journal of Dairy Science, 89(3), 812823.

Homayoni Rad, A., Vaghef Mehrabany, E., Alipoor, B., \& Vaghef Mehrabany, L. (2016). The Comparison of Food and Supplement as Probiotic Delivery Vehicles. Critical Reviews in Food Science and Nutrition, 56(6), 896-909. doi: $10.1080 / 10408398.2012 .733894$

Inglingstad, R. A., Devold, T. G., Eriksen, E. K., Holm, H., Jacobsen, M., Liland, K. H., .. Vegarud, G. E. (2010). Comparison of the digestion of caseins and whey proteins in equine, bovine, caprine and human milks by human gastrointestinal enzymes. Dairy Sci. Technol., 90(5), 549-563.

Irlinger, F., Ah Yuen In Yung, S., Sarthou, A., Delbès-Paus, C., Montel, M., Coton, M., ... Helinck, S. (2012). Ecological and aromatic impact of two Gram-negative bacteria (Psychrobacter celer and Hafnia alvei) inoculated as part of the whole microbial community of an experimental smear soft cheese. International Journal of Food MIcrobiology, 153, 332-338. doi:

10.1016/j.ijfoodmicro.2011.11.022

Janda, J. M., \& Abbott, S. L. (2006). The Genus Hafnia: from Soup to Nuts. Clinical Microbiology Reviews 19(1), 12-18. doi: 10.1128/CMR.19.1.12-28.2006

Janhoj, T., \& Qvist, K. B. (2010). The formation of Cheese Curd. In B. A. Law \& A. Y. Tamime (Eds.), Techology of Cheesemaking (pp. 130-156). United Kingdom Wiley-Blackwell.

Johnson, M., \& Law, B. A. (2010). The Origins, Development and Basic Operations of Cheesemaking Technology. In B. A. Law \& A. Y. Tamime (Eds.), Technology 
of CheesemakingSociety of Dairy Technology book series (2 ed., Vol. 1, pp. 6896). United Kingdom Blackwell Publishing Ltd.

Kong, F., \& Singh, R. P. (2008). Disintegration of Solid Foods in Human Stomach. Journal of Food Science, 73(5), R67-R80. doi: 10.1111/j.17503841.2008.00766.x

Kopf-Bolanz, K. A., Schwader, F., Gijs, M., Vergères, G., Portmann, R., \& Egger, L. (2014). Impact of milk processing on the generation of peptides during digestion. International Dairy Journal, 35(2), 130 -138. doi: 10.1016/j.idairyj.2013.10.012

Lay, C., Sutren, M., Lepercq, P., Juste, C., Rigottier-Gois, L., Lhoste, E., . . Andrieux, C. (2004). Influence of Camembert consumption on the composition and metabolism of intestinal microbiota: a study in human microbiota-associated rats. British Journal of Nutrition, 92, 429-438. doi: 10.1079/BJN20041192

Lazuka, A., Auer, L., Bozonnet, S., Morgavi, D. P., O'Donohue, M., \& HernandezRaquet, G. (2015). Efficient anaerobic transformation of raw wheat straw by a robust cow rumen-derived microbial consortium. Bioresource Technology, 196, 241-249. doi: 10.1016/j.biortech.2015.07.084

Lucey, J., Hauth, B., Gorry, C., \& Fox, P. (1993). The acid-base buffering properties of milk. Milchwissenschaft, 48(5), 268-272.

Lüthi-Peng, Q., \& Puhan, Z. (1999). Determination of protein and casein in milk by fourth derivative UV spectrophotometry. Analytica Chimica Acta 393(1-3), 227234. doi: 10.1016/S0003-2670(98)00823-X 
Magoč, T., \& Salzberg, S. L. (2011). FLASH: fast length adjustment of short reads to improve genome assemblies. Bioinformatics, 27(21), 2957-2963. doi:

\subsection{3/bioinformatics/btr507}

Marteau, P., Minekus, M., Havenaar, R., \& Huis In't Veld, J. H. J. (1997). Survival of Lactic Acid Bacteria in a Dynamic Model of the Stomach and Small Intestine: Validation and the Effects of Bile. Journal of Dairy Science, 80, 1031-1037. doi: 10.3168/jds.S0022-0302(97)76027-2

McDonald, D., Price, M. N., Goodrich, J., Nawrocki, E. P., DeSantis, T. Z., Probst, A., . .. Hugenholtz, P. (2012). An improved Greengenes taxonomy with explicit ranks for ecological and evolutionary analyses of bacteria and archaea. ISME J, 6(3), 610-618. doi:

http://www.nature.com/ismej/journal/v6/n3/suppinfo/ismej2011139s1.html

Ménard, O., Cattenoz, T., Guillemin, H., Souchon, I., Deglaire, A., Dupont, D., \& Picque, D. (2014). Validation of a new in vitro dynamic system to simulate infant digestion. Food Chemistry, 145, 1039-1045. doi:

10.1016/j.foodchem.2013.09.036

Mimouni, A., Deeth, H. C., Whittaker, A. K., Gidley, M. J., \& Bhandari, B. R. (2010). Investigation of the microstructure of milk protein concentrate powders during rehydration: Alterations during storage. Journal of Dairy Science, 93(2), 463 472. doi: $10.3168 /$ jds.2009-2369

Monnet, C., Landaud, S., Bonnarme, P., \& Swennen, D. (2014). Growth and adaptation of microorganisms on the cheese surface. FEMS Microbiology Letters, 263(1), 1-9. doi: $10.1093 /$ femsle/fnu025 
Prakash, S., Ma, Q., \& Bhandari, B. (2014). Rheological behaviour of selected commercially available baby formulas in simulated human digestive system. Food Research International, 64, 889-895. doi: 10.1016/j.foodres.2014.08.028

Ranadheera, C. S., Evans, C. A., Adams, C. A., \& Baines, S. K. (2012). In vitro analysis of gastrointestinal tolerance and intestinal cell adhesion of probiotics in goat's milk ice cream and yogurt. Food Research International, 49, 619-625. doi: 10.1016/j.foodres.2012.09.007

Rinaldi, L., Gauthier, S. F., Britten, M., \& Turgeon, S. L. (2014). In vitro gastrointestinal digestion of liquid and semi-liquid dairy matrixes. $L W T$ - Food Science and Technology 57(1), 99-105. doi: 10.1016/j.1wt.2014.01.026

Salaün, F., Mietton, B., \& Gaucheron, F. (2005). Buffering capacity of dairy products. International Dairy Journal, 15, 95-109. doi: 10.1016/j.idairyj.2004.06.007

Sanders, M. E., \& Marco, M. L. (2009). Food Formats for Effective Delivery of Probiotics. The Annual Reviews of Food Science and Technology, 1, 65-85. doi: 10.1146/annurev.food.080708.100743

Schlamowitz, M., \& Peterson, L. U. (1959). Studies on the Optimun pH for the Action of Pepsin on "Native" and Denatured Bovine Serum Albumin and Bovine Hemoglobin. The Journal of Biological Chemistry 234(12), 3137-3145.

Stocks, S. M. (2004). Mechanism and use of the commercially available viability stain, BacLight. Cytometry Part A, 61A(2), 189 - 195. doi: 10.1002/cyto.a.20069

Sumeri, I., Adamberg, S., Uusna, R., Sarand, I., \& Paalme, T. (2012). Survival of cheese bacteria in a gastrointestinal tract simulator. International Dairy Journal 25, 36-41. doi: 10.1016/j.idairyj.2011.12.016 
Sun, C. Q., O'Connor, C. J., \& Roberton, A. M. (2002). The antimicrobial properties of milkfat after partial hydrolysis by calf pregastric lipase. Chemico-Biological Interactions 140, 185-198. doi: Syneresis of submerged single curd grains and curd rheology

Turgeon, S. L., \& Rioux, L. (2011). Food matrix impact on macronutrients nutritional properties Food Hydrocolloids 25, 1915-1924. doi:

10.1016/j.foodhyd.2011.02.026

Upreti, P., Bühlmann, P., \& Metzger, L. E. (2006). Influence of Calcium and Phosphorus, Lactose, and Salt-to-Moisture Ratio on Cheddar Cheese Quality: pH Buffering Properties of Cheese. Journal of Dairy Science, 89, 938-950.

Uriot, O., Galia, W., Awussi, A. A., Perrin, C., Denis, S., Chalancon, S., . . Roussel, Y. (2016). Use of the dynamic gastro-intestinal model TIM to explore the survival of the yogurt bacterium Streptococcus thermophilus and the metabolic activities induced in the simulated human gut. Food Microbiology, 53, 18-29. doi: 10.1016/j.fm.2015.05.007

Voigt, D. D., Chevalier, F., Qian, M. C., \& Kelly, A. L. (2010). Effect of high-pressure treatment on microbiology, proteolysis, lipolysis and levels of flavour compounds in mature blue-veined cheese. Innovative Food Science \& Emerging Technologies, 11(1), 68-77. doi: http://dx.doi.org/10.1016/j.ifset.2009.10.009

Wang, Q., Garrity, G. M., Tiedje, J. M., \& Cole, J. R. (2007). Naïve Bayesian Classifier for Rapid Assignment of rRNA Sequences into the New Bacterial Taxonomy. Applied and Environmental Microbiology, 73(16), 5261-5267. doi:

10.1128/aem.00062-07 
Whittier, E. (1929). Buffer intensities of milk and milk constituents I. The buffer action of casein in milk. Journal of Biological Chemistry, 83(1), 79-88. 


\section{Figure captions}

Figure 1: Survival of HA in five matrices (S, WM, SM, GWM and GSM) during in vitro A) gastric, B) duodenal and C) intestinal compartments. * result of statistical analysis of time effect by matrix, ** result of statistical analysis of media effect at the same time of digestion.

Figure 2: Survival of BA in five matrices (S, WM, SM, GWM and GSM) during in vitro A) gastric, B) duodenal and C) intestinal compartments. * result of statistical analysis of time effect by matrix, ${ }^{* *}$ result of statistical analysis of media effect at the same time of digestion.

Figure 3: Confocal Laser Scanning Microscopy images showing the protein (yellow), the fat (green) and the microorganisms (red) in A) WM and in B) GWM. Live (green) and dead (red) cells of C) HA, D) BA and E) ST at pH7 and pH2.

Figure 4: Composition of the bacterial communities from fecal samples of individual mouse according to the day of sampling (d1, d5, d12) and the tested group (116: standard feeding; 131: whole milk, WM; 152: whole milk + microorganisms).

Figure 5: SDS page analysis of the evolution of proteolysis during gastric digestion of A) whole milk and B) rennet gel of whole milk. C: Kda protein standard

Figure 6: Kinetics of proteolysis of A) casein, B) $\beta$-lactoglobulin and $\alpha$-lactalbumin during gastric digestion of milk and gel.

Figure 7: Free Fatty Acids released during digestion of A) GWM and B) WM.

Figure 8: Evolution of the torque during digestion for milk and rennet gel matrices.

Figure 9: Buffering curves for synthetic medium, milk and rennet gel matrices during gastric phase in DIDGI ${ }^{\circledR}$ experiments. 


\section{Tables}

Table 1: Parameters used for in-vitro dynamic digestion.

\begin{tabular}{|c|c|c|c|c|}
\hline & Input & Concentration & $\begin{array}{l}\text { Quantity or } \\
\text { flow rate }\end{array}$ & Time lapse (min) \\
\hline \multirow{6}{*}{$\begin{array}{l}\text { Stomach } \\
37^{\circ} \mathrm{C}\end{array}$} & Matrix & & & \\
\hline & + & & $200 \mathrm{~mL}$ & 0 \\
\hline & Artificial saliva & & & \\
\hline & $\mathrm{HCl}$ & $0.5 \mathrm{M}$ & $\mathrm{pH}$ regulation & {$[0 ; 70]$} \\
\hline & Pepsin & 0.5 g. $\mathrm{L}^{-1}\left(\sim 2000 \mathrm{U} \cdot \mathrm{mL}^{-1}\right)$ & $0.4 \mathrm{~mL} \cdot \mathrm{min}^{-1}$ & {$[0 ; 90]$} \\
\hline & Gastric Lipase & 6.5 g. $\mathrm{L}^{-1}\left(\sim 200 \mathrm{U} \cdot \mathrm{mL}^{-1}\right)$ & $0.4 \mathrm{~mL} \cdot \mathrm{min}^{-1}$ & {$[0 ; 90]$} \\
\hline \multirow{8}{*}{$\begin{array}{l}\text { Duodenum } \\
37^{\circ} \mathrm{C}\end{array}$} & $\mathrm{Na}_{2} \mathrm{CO}_{3}$ & $1 \mathrm{M}$ & $\mathrm{pH}$ regulation & \\
\hline & Bile 40 & 40 g. $\mathrm{L}^{-1}$ & $10 \mathrm{~mL}$ & 0 \\
\hline & & & $0.5 \mathrm{~mL} \cdot \mathrm{min}^{-1}$ & {$[0 ; 80]$} \\
\hline & Bile 20 & 20 g. $\mathrm{L}^{-1}$ & $0.15 \mathrm{~mL} \cdot \mathrm{min}^{-1}$ & {$[80 ; 100]$} \\
\hline & & & $0.2 \mathrm{~mL} \cdot \mathrm{min}^{-1}$ & {$[80 ; 220]$} \\
\hline & Pancreatin & 20 g. $\mathrm{L}^{-1}$ & $5 \mathrm{~mL}$ & 0 \\
\hline & & & $0.25 \mathrm{~mL} \cdot \mathrm{min}^{-1}$ & {$[0 ; 50]$} \\
\hline & & & $0.1 \mathrm{~mL} \cdot \mathrm{min}^{-1}$ & {$[50 ; 220]$} \\
\hline Intestine & Diluent & & $0.8 \mathrm{~mL} \cdot \mathrm{min}^{-1}$ & {$[10 ; 100]$} \\
\hline (Jejunum and ileum) & & & $0.5 \mathrm{~mL} \cdot \mathrm{min}^{-1}$ & {$[100 ; 250]$} \\
\hline $37^{\circ} \mathrm{C}$ & & & & \\
\hline
\end{tabular}


Figures
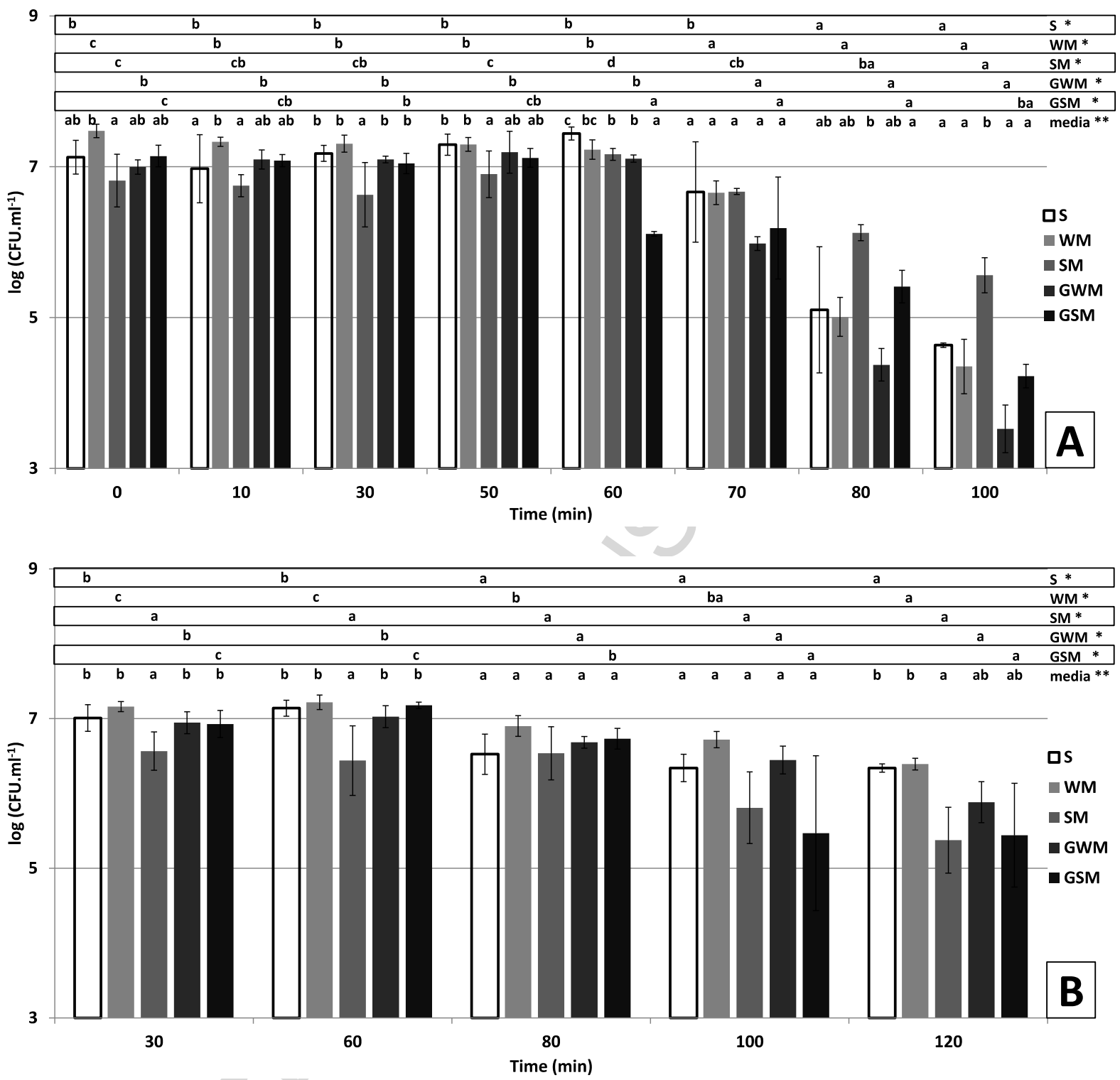


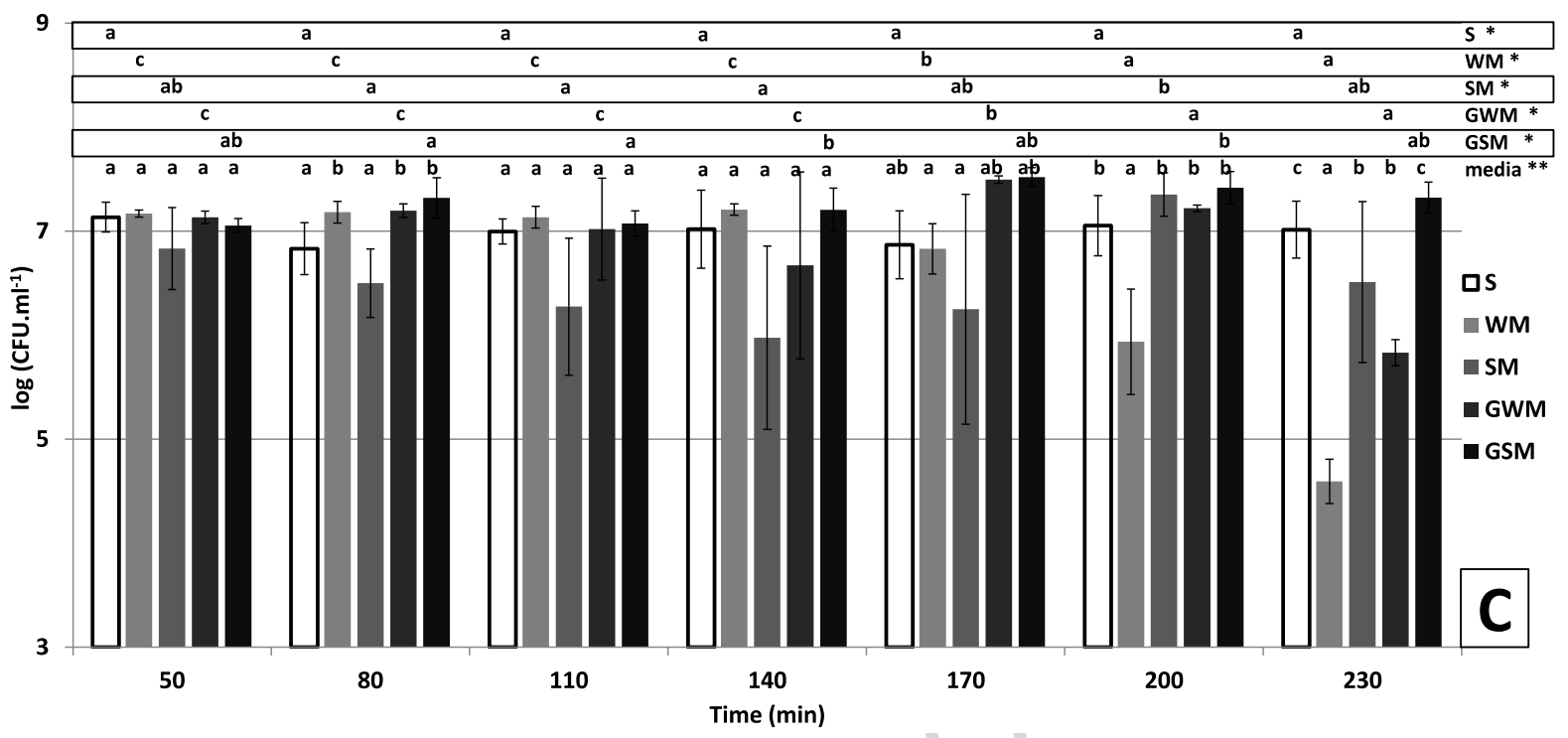

Figure 1

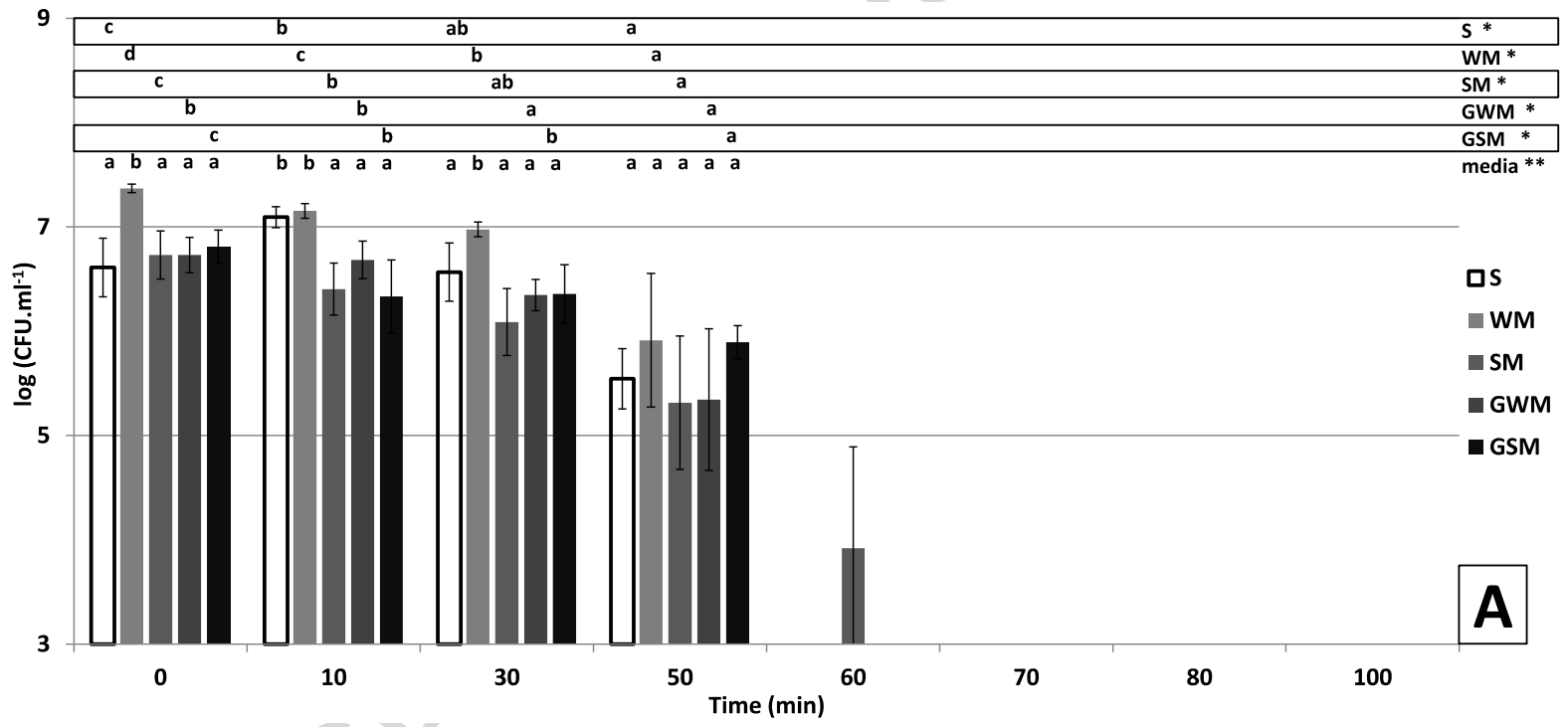



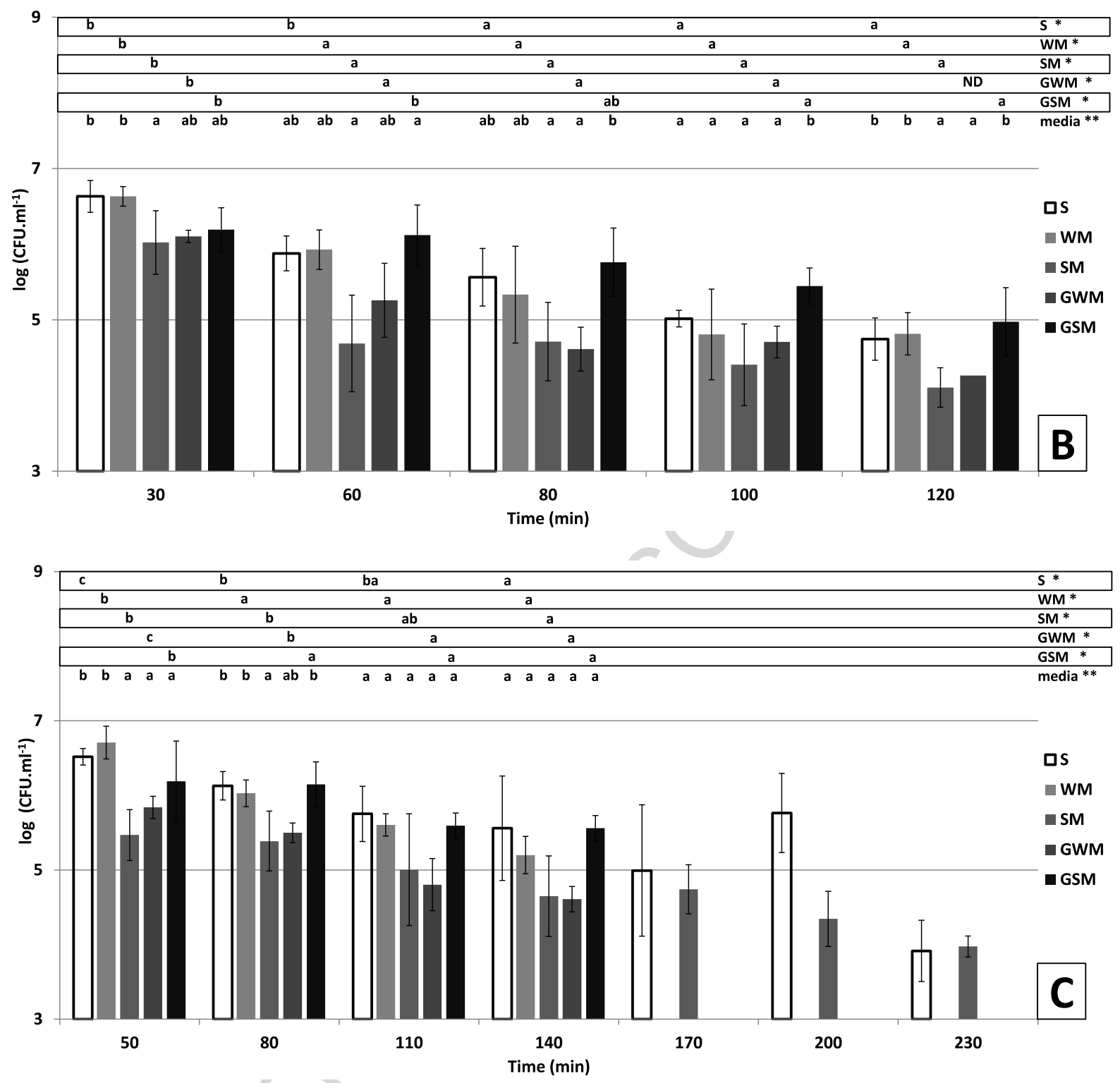

Figure 2 

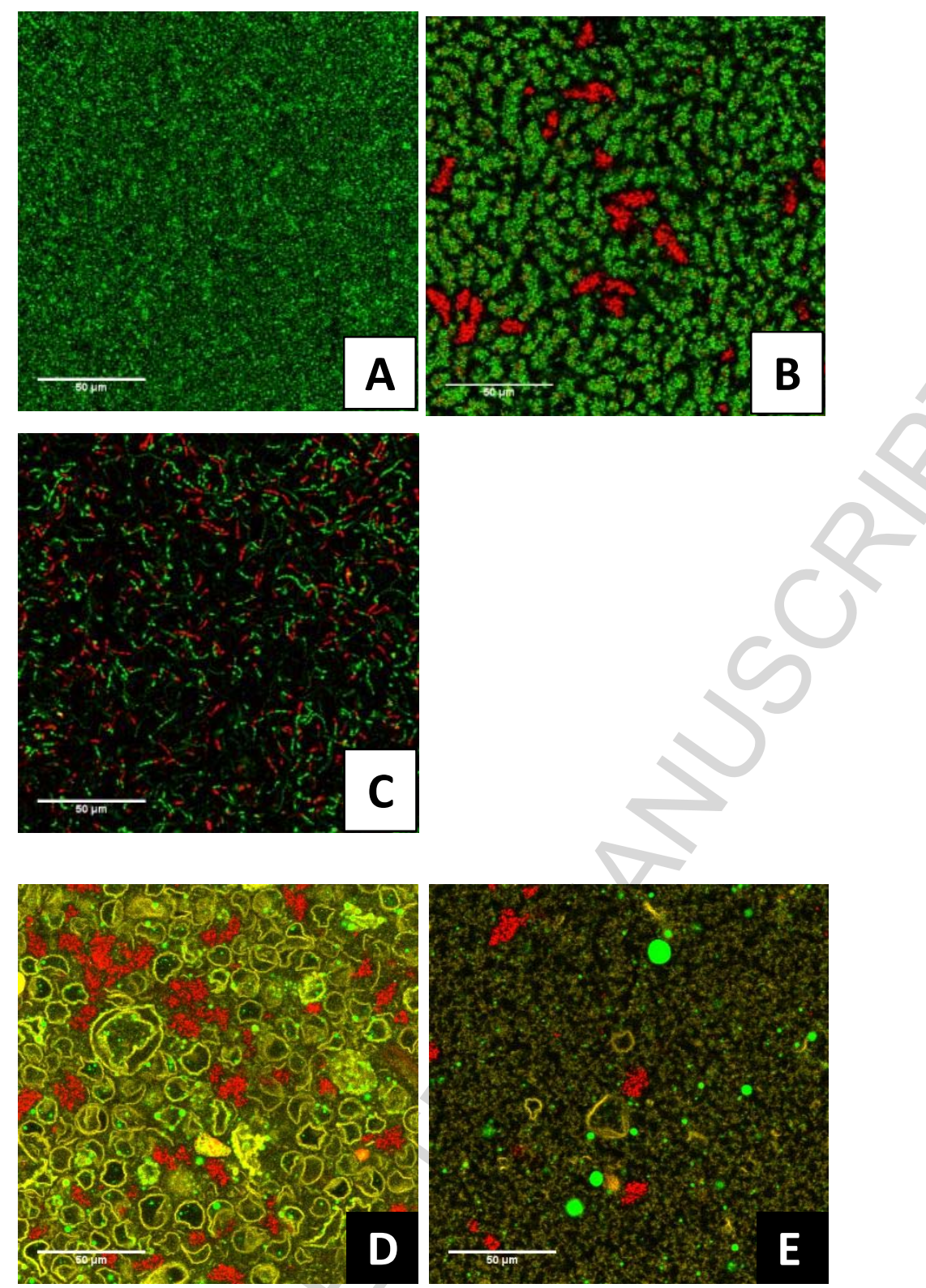

Figure 3

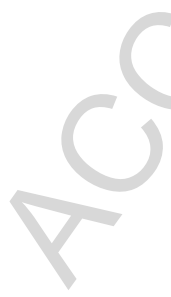




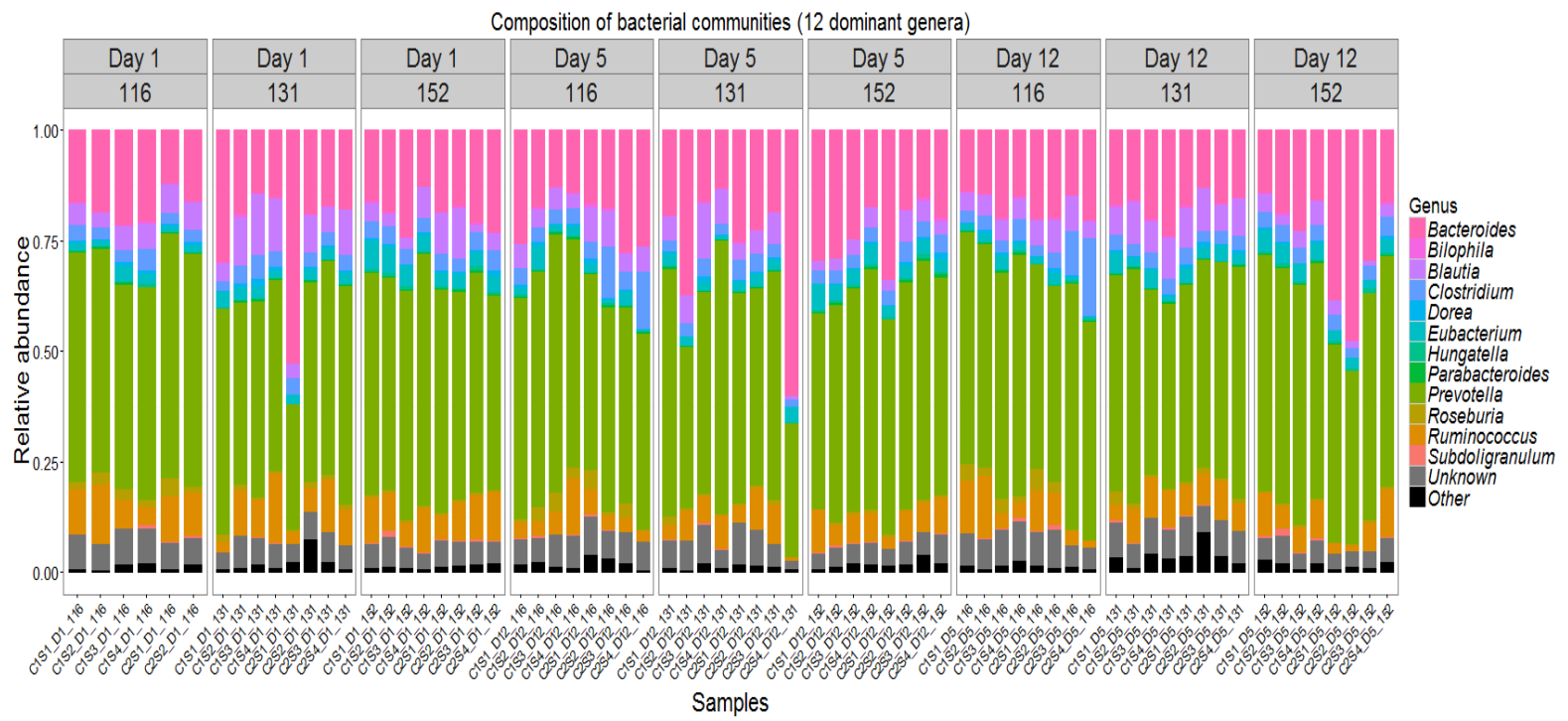

Figure 4 


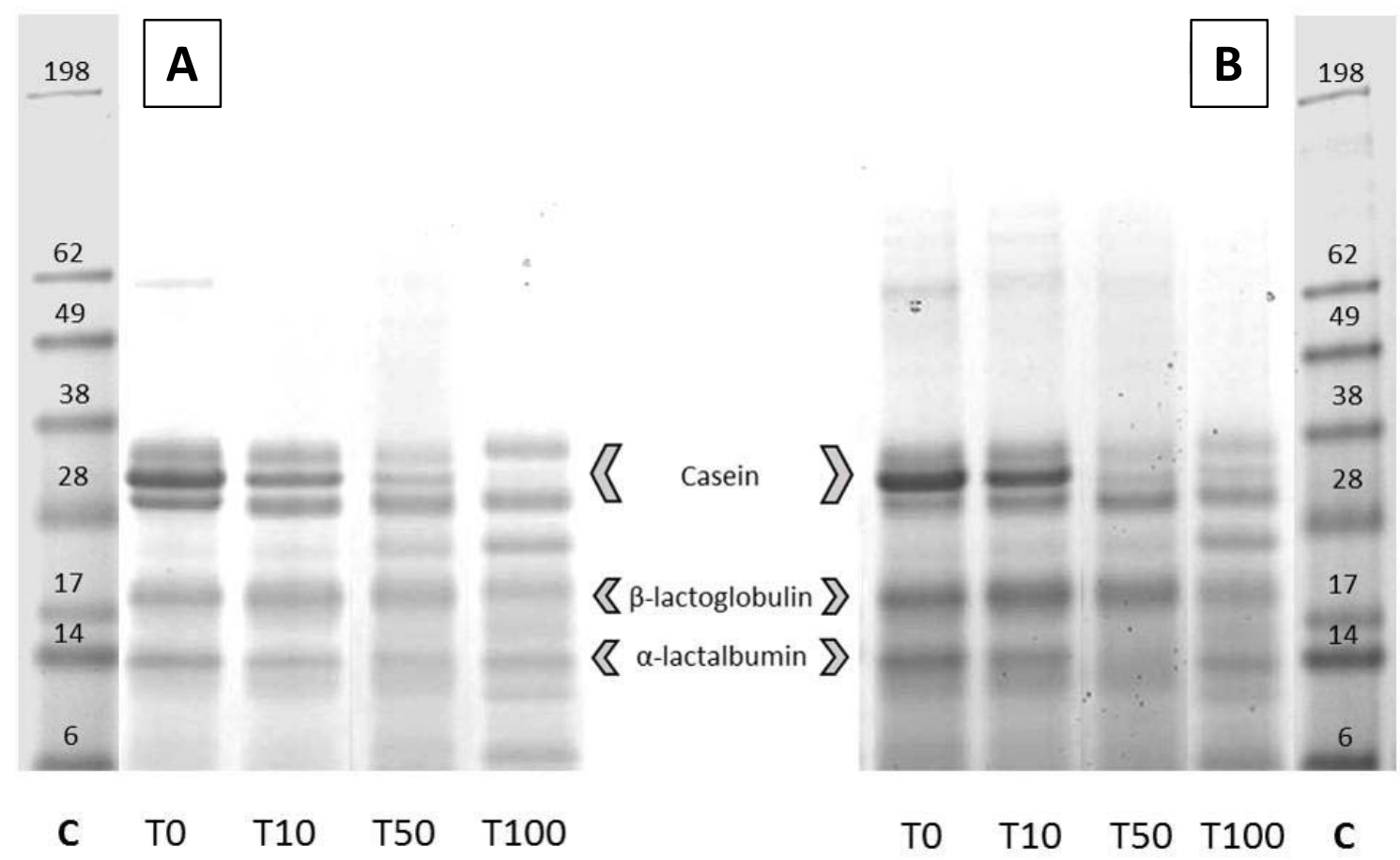

Figure 5

Comment citer ce document : 

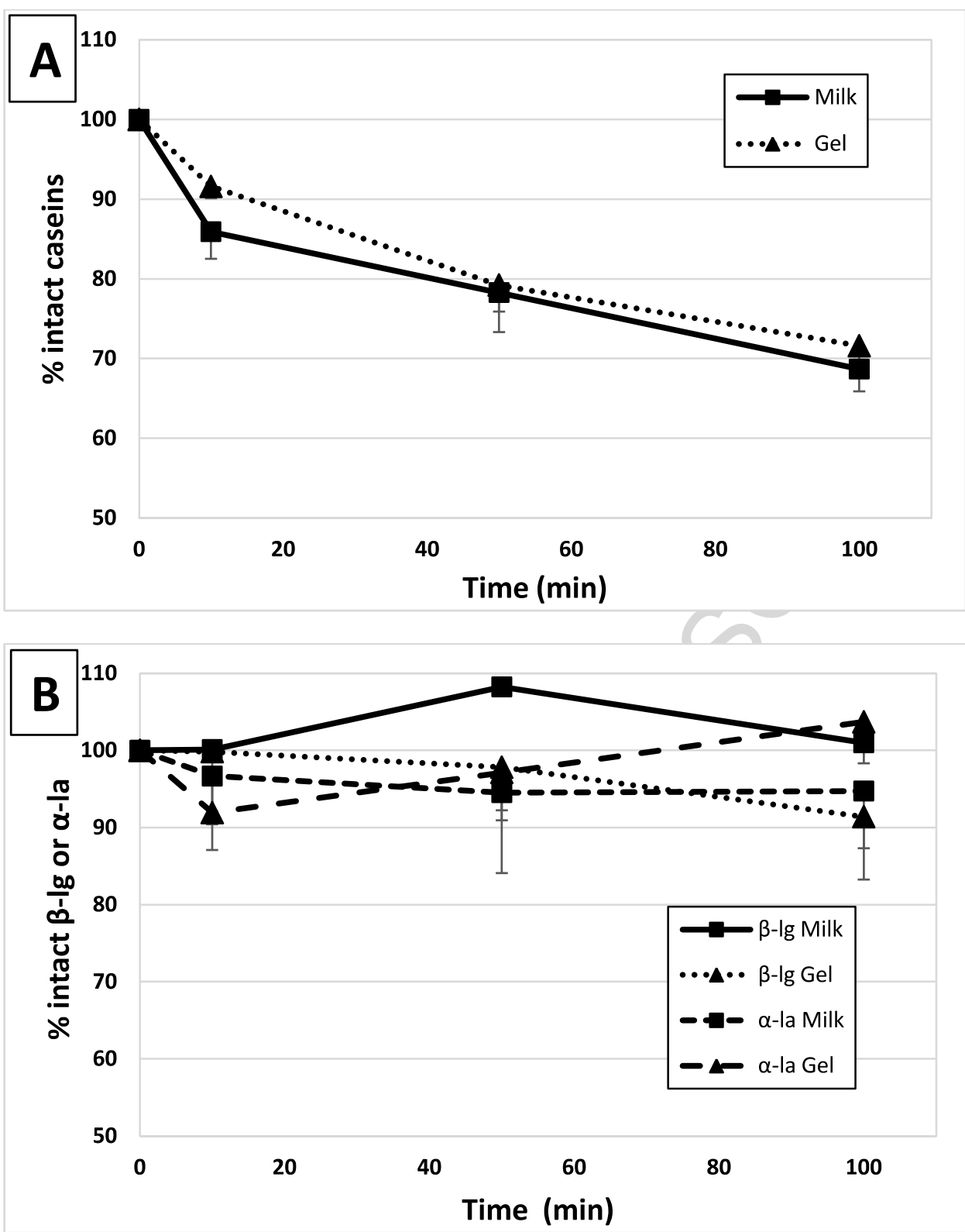

Figure 6 

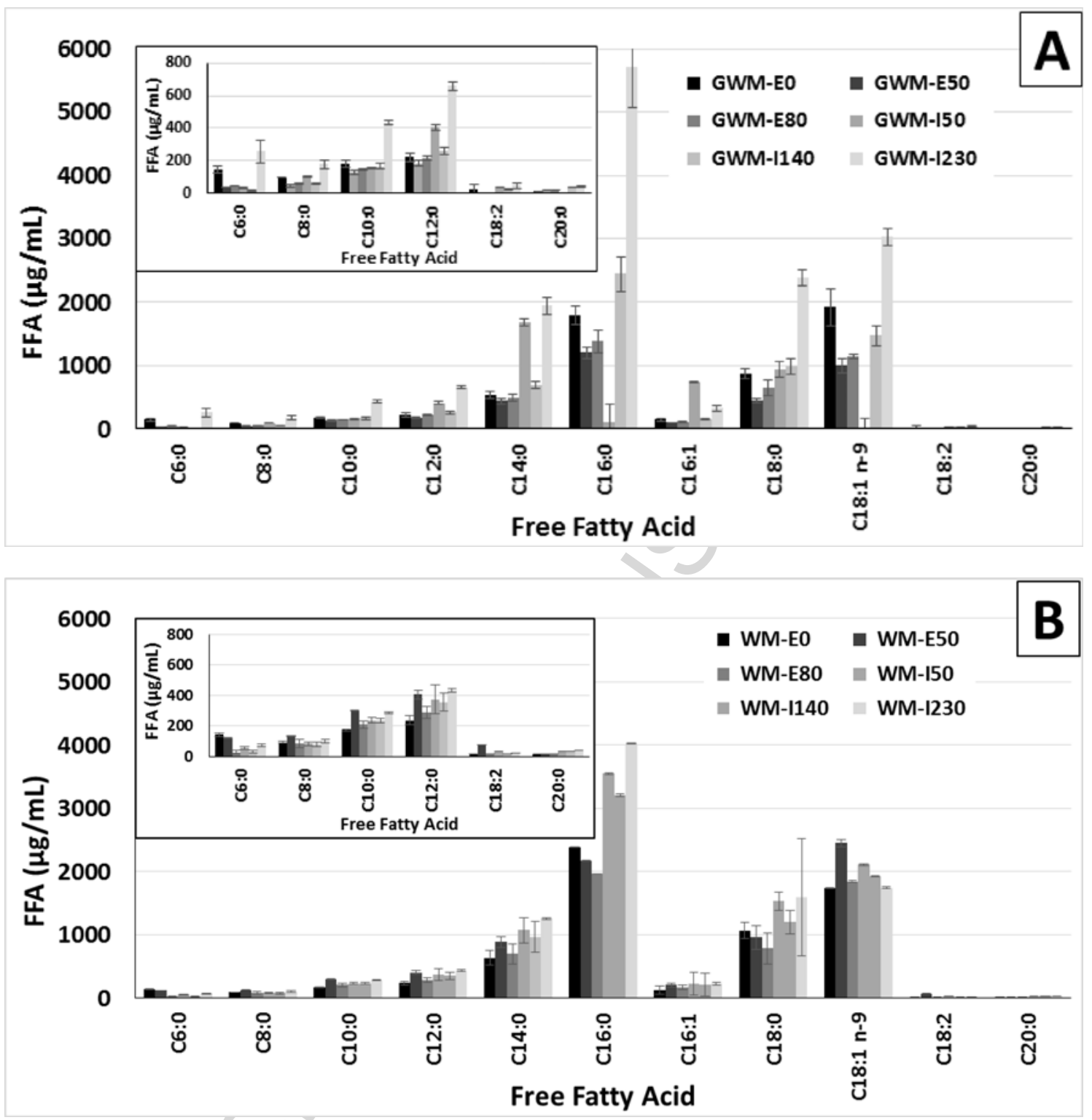

Figure 7 


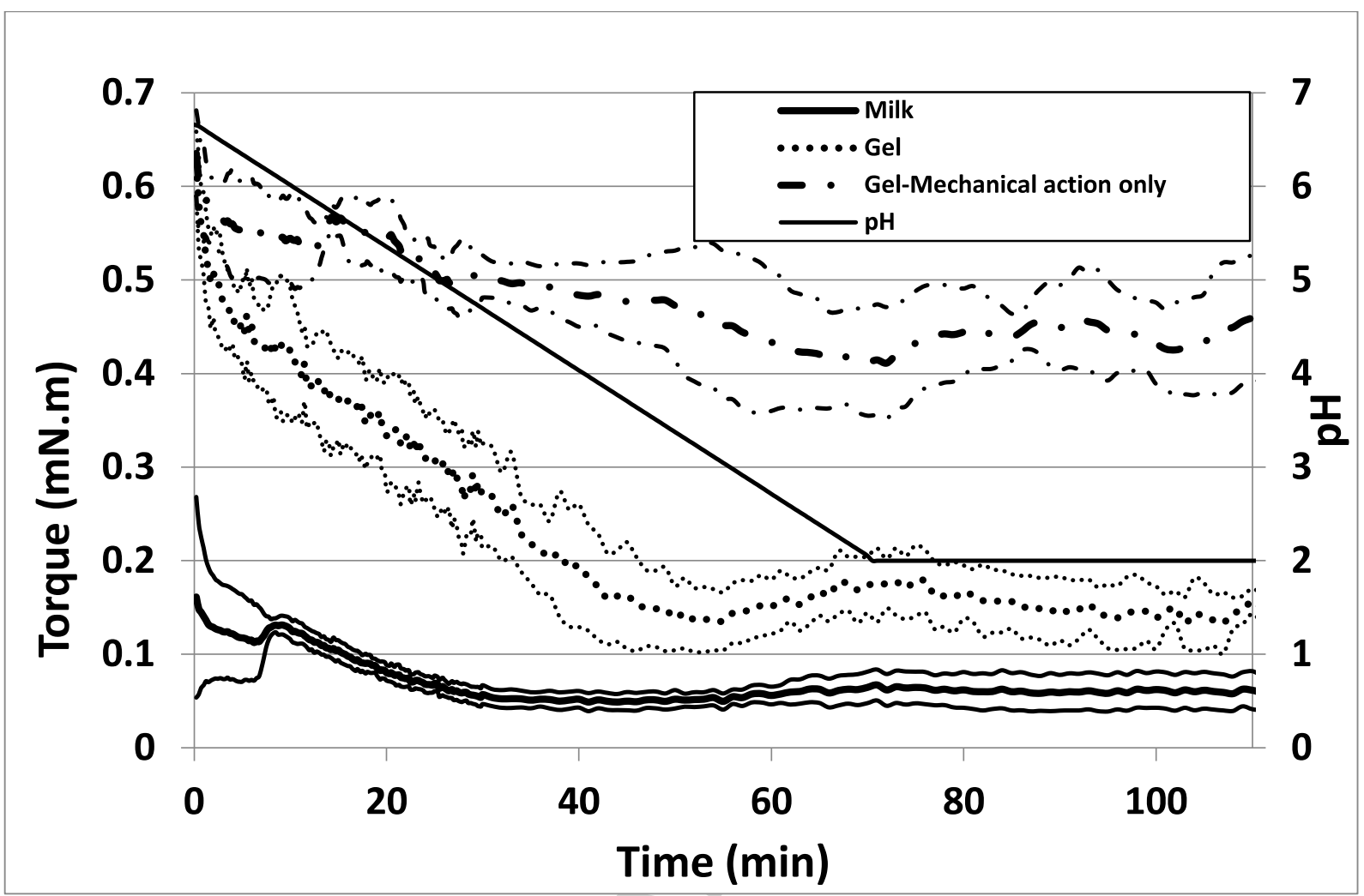

Figure 8 


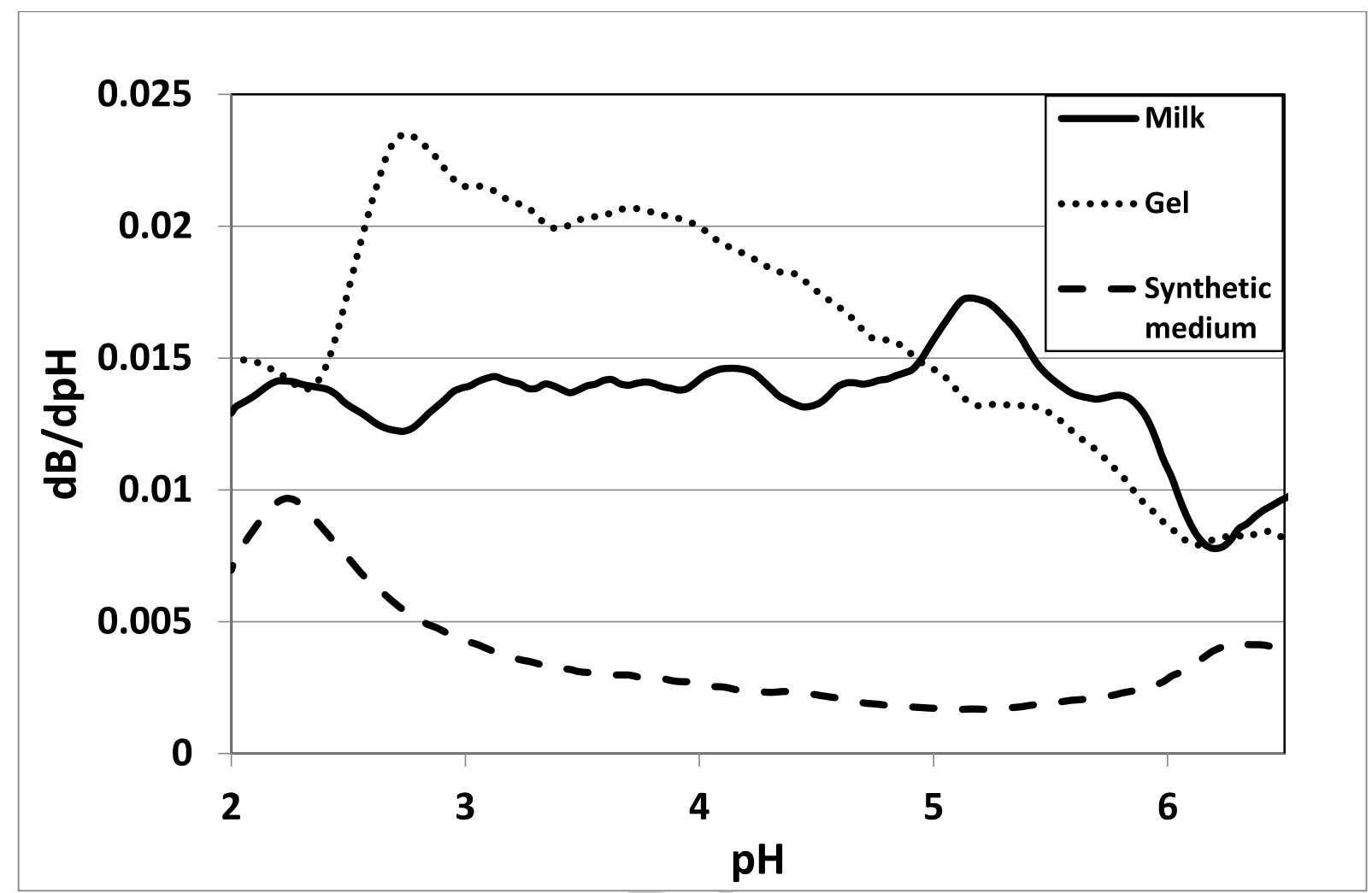

Figure 9 
Effect of dairy matrices on the survival of Streptococcus thermophilus, Brevibacterium aurantiacum and Hafnia alvei during digestion

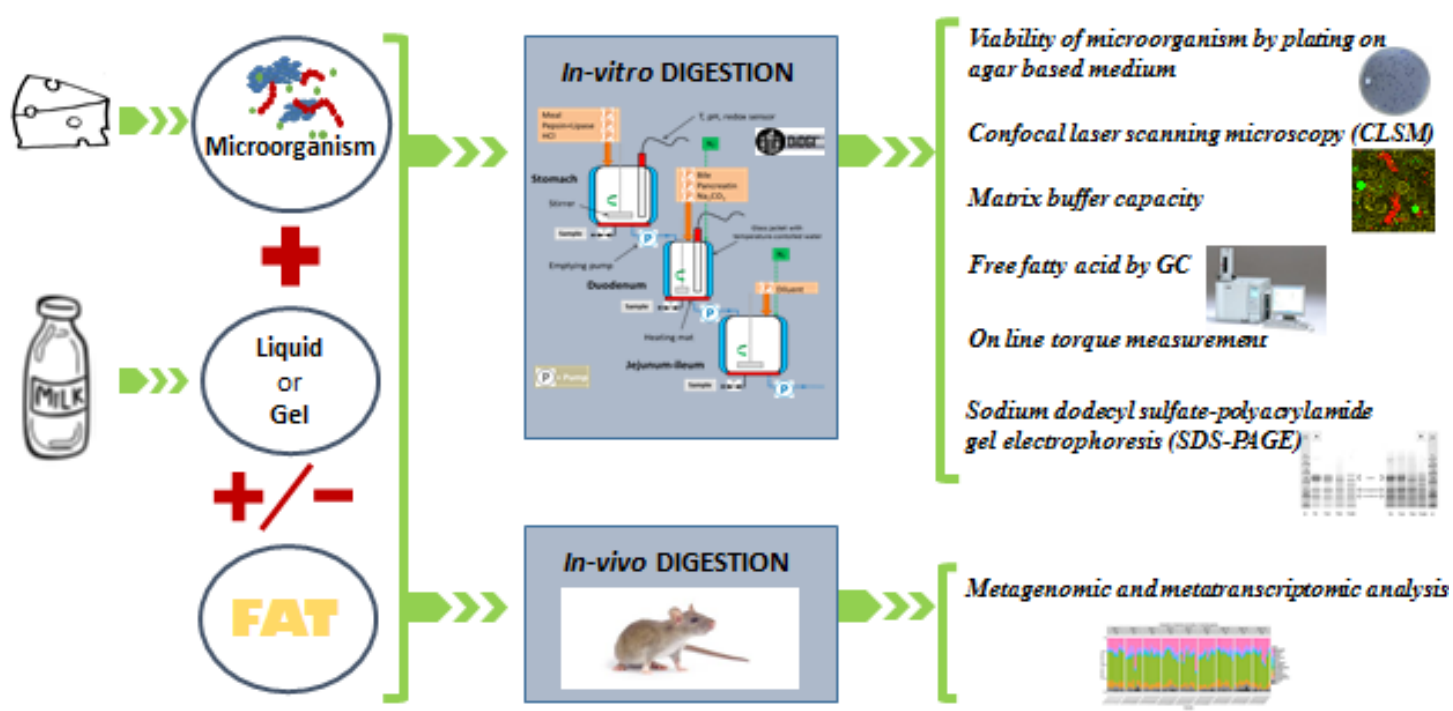

Graphical abstract 


\section{Highlights}

- Stomach acidification was the main cause of microorganism mortality

- Dairy matrix structure and composition had no influence on microorganisms survival.

- Resistance of microorganisms to digestive stress was strain-dependent. 